The

University

of Chicago

Law Review

VOLUME 40 NUMBER 1 FALL 1972

\title{
Summary Action by Administrative Agencies
}

\author{
James O. Freedman†
}

In framing a government which is to be administered by men over men, the great difficulty lies in this: you must first enable the government to control the governed; and in the next place oblige it to control itself.

James Madison, The Federalist No. 51

More than 90 percent of the work of the federal administrative agencies is done informally, without an adjudicatory hearing. ${ }^{1}$ One of the most important and least studied of the informal procedures used by administrative agencies, both federal and state, is summary action - sometimes called emergency action or temporary action-pending an adjudicatory hearing. The justification for summary action lies in the necessity for the government to act immediately--against an epidemic of a contagious disease, against the distribution of putrid meat or adulterated drugs, against the sale of worthless securities, against bank officers whose conduct is jeopardizing the interests of depositors-if public policy is to be enforced at all. If an administrative agency were

+ Professor of Law, University of Pennsylvania. This article is based on a report prepared for the Administrative Conference of the United States, but responsibility for its contents is mine. I am profoundly indebted to Louis Corsi of the Class of 1972, University of Pennsylvania Law School, for his imaginative, devoted, and painstaking assistance.

1 See K. Davis, Administrative Law Text $\S 4.01$, at 88 ( $9 \mathrm{~d}$ ed. 1972); K. Davis, Discretionary Justige, A Preliminary Inquiry 21 (1969); Final REPort of the ATtorney General's Comm. on Administrative Procedure, S. Doc. No. 8, 77th Cong., 1st Sess. 35 (1941). 
to provide a hearing before acting in such circumstances, the attendant delay would often render any eventual action or order ineffective to protect the public interest. Yet the asserted factual basis for a particular exercise of summary authority may be quite in error, as a prior hearing might have revealed, and the person against whom summary action is taken may never completely recover from the drastic impact it may have.

In weighing the need for effective administrative action against the possibility of error in the administrative determination to act, the law has struck the balance in favor of permitting summary action in certain circumstances. This balance may be the only one consistent with effective public administration. But it unavoidably raises questions as to the permissible uses and limits of summary action-as a matter of history, as a matter of the Constitution, and as a matter of wise policy.

The use of summary procedures by the states has its roots in the common law of nuisance. The Supreme Court, in tracing the history of summary action, noted that "the summary abatement of nuisances without judicial process or proceeding was well known to the common law long prior to the adoption of the Constitution."2 By placing this common law authority to act against nuisances at the service of the police power, the states were able to reach any circumstance that could plausibly be related to the public health, safety, or morals. The result, given the deference that nineteenth century courts paid to state exercises of the police power, was to extend summary authority to conduct and conditions that earlier generations of common lawyers could hardly have foreseen.

What kinds of conduct and conditions did the states' summary authority reach? Statutes permitting the seizure and destruction of unwholesome food, particularly meat and milk, were common, ${ }^{3}$ as were statutes permitting the destruction of diseased animals, ${ }^{4}$ diseased trees, ${ }^{5}$ and goods, such as liquor, whose use was illegal. ${ }^{6}$ States also

2 Lawton v. Steele, 152 U.S. 133, 142 (1894); see People ex rel. Copcutt v. Board of Health, 140 N.Y. 1, 35 N.E. 320 (1893). See generally Powell, Administrative Exercise of the Police Power, 24 Harv. L. REv. 333, 336-38 (1911).

3 See, e.g., Adams v. Milwaukee, 228 U.S. 572 (1913); North Am. Cold Storage Co. v. Chicago, 211 U.S. 306 (1908); People ex rel. Lodes v. Department of Health, 189 N.Y. 187, 82 N.E. 187 (1907).

4 See, e.g., State v. Schriber, 185 Ore. 615, 205 P.2d 149 (1949). It was a Massachusetts statute declaring horses with the glanders to be a nuisance that gave rise to Justice Holmes's celebrated opinion in Miller v. Horton, I52 Mass. 540, 26 N.E. 100 (1891).

5 See, e.g., Miller v. Schoene, 276 U.S. 272 (1928); Balch v. Glenn, 85 Kan. 735, 119 P. 67 (1911).

o See, e.g., Samuels v. McCurdy, 267 U.S. 188 (1925); People v. Diamond, 233 N.Y. 130, 135 N.E. 200 (1922). 
enacted statutes permitting the seizure of banks thought to be at the brink of insolvency, ${ }^{7}$ the suspension of proposed utility rates and the entry of temporary rate orders, ${ }^{8}$ and the demolition of houses falling to decay or standing in the path of a conflagration. ${ }^{9}$

While they continue to act under these and similar statutes, the most important uses to which the states put summary action today are probably in matters involving licensing. State agencies typically have the authority to suspend a license summarily, pending a hearing on the merits, when it appears that the licensee has acted in a manner that threatens the public health or safety. Because of the many occupations and activities subject to state licensing requirements, ${ }^{10}$ this authority potentially affects a large number of citizens.

The authority of the states to act summarily has thus been as extensive as the substantive reach of the law of nuisance and of the police power. The federal government, on the other hand, has exercised its authority to act summarily in fewer substantive areas, primarily those of economic regulation. Nonetheless, because of the decisive position of federal administrative agencies in regulating the national economy, summary action by the federal government has been at least as significant as that of the states. Various federal agencies have summary authority to seize adulterated or misbranded foods, drugs, cosmetics, and hazardous substances; 11 to appoint conservators to take possession of banks whose financial structures are thought to be precarious; ;2 $^{12}$ to halt trading in certain securities; ${ }^{13}$ and to suspend many of the

7 See, e.g., State Sav. \& Commercial Bank v. Anderson, 165 Cal. 437, 132 P. 755 (1913), aff'd, 238 U.S. 611 (1915). But see National Auto. Serv. Corp. v. Barfod, 289 Pa. 307, 137 A. 601 (1927).

8 See, e.g., Driscoll v. Edison Light \& Power Co., 307 U.S. 104 (1989).

○ See, e.g., Jackson v. Bell, 143 Tenn. 452, 266 S.W. 207 (1920); Genesse Recreation Co. v. Edgerton, 172 App. Div. 464, 158 N.Y.S. 421 (1916).

10 See W. Gellhorn, Individual Fremdom and Governmental Restraints 106 (1956); cf. Note, Entrance and Disciplinary Requirements for Occupational Licenses in California, 14 StAN. L. Rev. 533, 534 (1962).

11 Federal Hazardous Substances Labeling Act § 6, 15 U.S.C. § 1265 (1964), as amended, 15 U.S.C. § 1265 (1970); Food, Drug, and Cosmetic Act § 304, 21 U.S.C. § 334 (1970), amending 21 U.S.C. $\$ 334$ (1964); Drug Abuse Control Amendments of 1965 \& 8(a), 21 U.S.C. § 372(e) (1970); Federal Meat Inspection Act \$§ 3-6, 7(e), 21 U.S.C. §§ 603-06, 607(e) (1970).

12 Home Owners' Loan Act of 1933 \&(d), 12 U.S.C. \& 1464(d) (1970), as amended by Pub. L. No. 89-695 (Oct. 16, 1966) (appointment of a conservator or receiver subject to judicial removal within thirty days on petition of the savings association).

13 Securities and Exchange Act of $1934 \S \S 15(c)(5), 19(a)(4), 15$ U.S.C. $\S \S 780$ (c)(5), $78 s(a)(4)$ (1970). The SEC's authority to enter "stop orders" against misleading registration statements may be exercised only after a hearing, Securities Act of 1933 \& $8(d)$, 15 U.S.C. $\S 77 \mathrm{~h}$ (d) (1970), but the impact of the announcement that such a hearing will be held has so great an effect in the marketplace that the authority is often regarded as summary. See Jones v. SEC, 298 U.S. 1 (1936); J. LANDIS, The Administrative Process 107-09 (1938). 
various licenses that the federal government requires to engage in particular activities. ${ }^{14}$ A number of federal agencies have the authority to suspend summarily the effective date of proposed tariff schedules submitted by carriers, ${ }^{15}$ an authority that has been described as "one of the most useful and important powers in the entire field of administrative regulation." ${ }^{16}$ Finally, the Commissioner of Internal Revenue may summarily impose a jeopardy assessment, thereby permitting the government to levy against a taxpayer's property in advance of any adjudicatory determination that a tax is owing. ${ }^{17}$

The Constitution requires that whenever the government must provide an adjudicatory hearing for the determination of an issue, the hearing must "be granted at a meaningful time and in a meaningful manner."18 Whether the constitutional standard of meaningfulness requires that the hearing be held before the government takes any action is a proper subject for case-by-case determination. A number of recent Supreme Court decisions indicate that in most circumstances the due process requirement of a hearing can be satisfied only by a prior hearing. ${ }^{19}$ They suggest that many of the Court's earlier decisions sustaining summary procedures against due process challenges rested upon the existence of "extraordinary"20 or "emergency" 21 circumstances in which summary action was "essential to protect a vital governmental interest." 22 Part I of this article examines both the earlier decisions sustaining the constitutionality of summary action and the more recent decisions holding particular exercises of summary authority

14 E.g., United States Cotton Standards Act § 8, 7 U.S.C. § 53 (1970); United States Grain Standards Act $\S 7,7$ U.S.C. § 85 (1970); Federal Aviation Act $\S 609,1005(2), 49$ U.S.C. §§ 1429, 1485(a) (1970); 21 C.F.R. § 8.28 (1971).

15 E.g., Natural Gas Act § 4(e), 15 U.S.C. § 717c(e) (1970); Federal Power Act § 205(e), 16 U.S.C. § 824d(e) (1970); Intercoastal Shipping Act § \$, 46 U.S.C. § 845 (1970); Federal Communications Act § 204, 47 U.S.C. § 204 (1970); Interstate Commerce Act §§ I5(7), $216(\mathrm{~g}), 218(\mathrm{c}), 406(\mathrm{e}), 907(\mathrm{~g}), 49$ U.S.C. $\$ \S 15(7), 316(\mathrm{~g}), 318(\mathrm{c}), 1006(\mathrm{e}), 907(\mathrm{~g})(1970)$; Federal Aviation Act $\S 1002$, 49 U.S.C. $\S 1482(\mathrm{~g})$ (1970).

16 Report on Practices and Procedures of Governmental Control of TransportaTION, H. R. Doc. No. 678, 78th Cong., 2d Sess. 96 (1944).

17 INT. REv. CODE OF 1954, § 6861.

18 Armstrong v. Manzo, 380 U.S. 545, 552 (1965). See also Mullane v. Central Hanover Trust Co., 339 U.S. 306, 313 (1950); Grannis v. Ordean, 234 U.S. 385, 394 (1914).

19 See Fuentes v. Shevin, 407 U.S. 67 (1972); Bell v. Burson, 402 U.S. 535 (1971); Wheeler v. Montgomery, 397 U.S. 280 (1970); Goldberg v. Kelly, 397 U.S. 254 (1970); Sniadach v. Family Finance Corp., 395 U.S. 337 (1969); cf. Morrissey v. Brewer, 408 U.S. 471 (1972); Wisconsin v. Constantineau, 400 U.S. 433 (1971).

20 Sniadach v. Family Finance Corp., 395 U.S. 337, 339 (1969); see Board of Regents of State Colleges v. Roth, 408 U.S. 564, 570 n.7 (1972).

21 Bell v. Burson, 402 U.S. 535, 542 (1971).

22 Sniadach v. Family Finance Corp., 395 U.S. 337, 343 n.* (1969) (Harlan, J., concurring); see Boddie v. Connecticut, 401 U.S. 371, 379 (1971). 
unconstitutional, in an effort to identify the contemporary constitutional limits of the exception to the norm of a prior hearing.

While the courts have the power to define the constitutional limitations upon the use of summary action, the legislatures-and particularly the Congress of the United States, with its power to occupy many regulatory fields-have the initial responsibility to decide whether to authorize particular agencies to act summarily in particular circumstances; and the agencies have the initial responsibility to determine whether to exercise their summary authority in specific situations. Part II of this article examines the performance of the federal administrative agencies in exercising summary authority and analyzes particular proposals by which Congress and the agencies can improve that performance. It addresses the problem of controlling the use of summary authority without sacrificing its effectiveness. Part III of this article considers the wisdom of empowering administrative agencies to seek preliminary injunctions from the federal courts as an alternative to authorizing them to take summary action.

\section{Summary Agtion and the Constitution}

In determining when the Constitution should be read to permit an administrative agency to act summarily pending an adjudicatory hearing, the courts have engaged in the intellectual process, often employed in constitutional adjudication, of balancing one competing interest against another, one value against another with which it conflicts. The Supreme Court has addressed this problem in about a dozen decisions, extending over a century and touching a wide range of substantive concerns. Although, here as elsewhere, generalizations are hazardous, the factors that the Court has taken into account in the process of creating the constitutional law of summary action are susceptible to systematic analysis.

\section{A. The Logic of Statutory Authorization}

The question of when the Constitution should be read to permit an administrative agency to act summarily can perhaps be put with a more useful precision: when should the Constitution be read to permit the legislature to authorize an administrative agency to act summarily? This formulation directs attention to two important threshold considerations.

First, in considering challenges to summary action, courts properly begin by assuring themselves that the legislature has given the agency 
statutory authority to act summarily. ${ }^{23}$ Administrative agencies exercise delegated powers. The question of what powers the legislature has delegated to an agency is never a matter of indifference, either to the legislature, the agency, or those subject to the agency's regulatory jurisdiction, particularly when the powers in issue are significant. The power to act summarily is a drastic and sensitive one, akin to the injunctive power of a court; it is granted to agencies, usually those having the confidence of the legislature, only for the performance of a limited number of tasks. Given the political process by which administrative agencies are brought to birth and the drastic nature of the power to act summarily, it is justifiable to assume that a legislature's failure to delegate summary authority was not inadvertent. Whatever arguments can be made in favor of implying the existence in an agency of particular powers not expressly or precisely delegated, they are not appropriate to the power to act summarily..$^{24}$

Moreover, any assertion of authority to act summarily potentially presents questions of constitutional dimension, particularly with respect to the limitations summary action may impose on the right to a hearing. By enforcing a requirement of statutory authorization, courts insure that they will confront these questions only when the legislature has focused upon them as a matter of policy and has unambiguously elected to present them. ${ }^{25}$ Courts thereby avoid imputing to the legislature the intention to enact laws presenting serious constitutional questions when the legislature's intention is far from clear. ${ }^{26}$ The

23 See, e.g., National Airlines, Inc. v. CAB, 306 F.2d 753, 758 (D.C. Cir. 1962); Nebraska Dep't of Aeronautics v. CAB, 298 F.2d 286 (8th Cir. 1962). Agencies asserting the power to act summarily without statutory authorization have been rebuffed by the courts. See, e.g., Kirby v. Shaw, 358 F.2d 446 (9th Cir. 1966); Standard Airlines, Inc. v. CAB, 177 F.2d 18 (D.C. Cir. 1949); cf. Trans-Pacific Freight Conference v. Federal Maritime Bd., 302 F.2d 875, 880 (D.C. Cir. 1962) (agency sought to establish that Congress had granted it statutory authority to act summarily, rather than asserting that such authority was unnecessary; summary order set aside for want of authority). But cf. Silver v. McCamey, 221 F.2d 873 (D.C. Cir. 1955).

24 Cf. L.P. Steuart \& Bro. v. Bowles, 322 U.S. 398 (1944). It is doubtful, therefore, whether a statute authorizing an agency "to promulgate regulations for [its] efficient enforcement," Food, Drug, and Cosmetic Act \& 701(a), 21 U.S.C. \& 371(a) (1970), can properly be construed by an agency to authorize regulations providing for summary license suspensions. But see id. and 21 C.F.R. § 8.28 (1971); Securities Act of 1933 §3(b), 15 U.S.C. § 77c(b) (1970) and 17 C.F.R. \$§ 230.251-.262 (1971).

25 See Greene v. McElroy, 360 U.S. 474 (1959); Kent v. Dulles, 357 U.S. 116 (1958); Freedman, The Uses and Limits of Remand in Administrative Law: Staleness of the Record, 115 U. PA. L. REV. 145, 152-57 (1966).

26 See, e.g., Stanard v. Olesen, 74 S. Ct. 768 (Douglas, Gircuit Justice, 1954) (refusal to infer Post Office authority to impound mail summarily pending a hearing on mail fraud charges in light of the "constitutional implications" of such authority); A. BIckEL, TrE LEAST DANGEROUS BRANCH 111-98 (1962). 
requirement of statutory authorization thus allows the courts both to respect the legislature's prerogative and to enforce its responsibility of initial decision in matters likely to have a constitutional dimension. It also serves to maintain the integrity of the judicial process by avoiding premature adjudication of constitutional questions.

Second, the fact that the legislature, after weighing the need for prompt action against the protections afforded by a prior hearing, has authorized an administrative agency to act summarily often seems itself to be a persuasive element in the judicial determination that the authorization is constitutional. ${ }^{27}$ For example, in North American Cold Storage Co. $v$. Chicago, ${ }^{28}$ the Supreme Court said:

What is the emergency which would render a hearing unnecessary? We think when the question is one regarding the destruction of food which is not fit for human use the emergency must be one which would fairly appeal to the reasonable discretion of the legislature as to the necessity for a prior hearing, and in that case its decision would not be a subject for review by the courts. ${ }^{29}$

It is clearly appropriate for courts to respect a legislative judgment that, on the balance of risks, summary action is necessary for effective administrative regulation, if only because the legislature is more likely to be adequately informed on such matters than a court. At the same time, however, reliance on the legislature's judgment would have too much the quality of bootstrapping if it were permitted to do service by itself. A recent series of decisions in which the Supreme Court has held certain summary procedures unconstitutional suggests that statutory authorization, taken alone, is not dispositive of the question of constitutionality. That question requires reference to standards that are in the ultimate keeping of courts; there remains the eminently judicial task of inquiring into the asserted justification for each statutory grant of summary authority.

\section{B. Situations Justifying Summary Action}

An understanding of the circumstances in which summary action is constitutionally permissible must begin by recognizing the historic role in our legal system of adversary hearings in resolving factual

27 See, e.g., Phillips v. Commissioner, 283 U.S. 589, 594 (1931); R.A. Holman \& Co. v. SEC, 299 F.2d 127, 132-83 (D.C. Cir.), cert. denied, 370 U.S. 911 (1962).

28211 U.S. 306 (1908).

20 Id. at 320; see Ewing v. Mytinger \& Casselberry, Inc., 339 U.S. 594 (1950); Nor-Am Agricultural Prods., Inc. v. Hardin, 435 F.2d 1151, 1160 (7th Cir. 1970), petition for cert. dismissed, 402 U.S. 935 (1971); Greater Del. Valley Fed. Sav. \& Loan Ass'n v. FHLBB, 262 F.2d 371, 374 (3d Cir. 1958). 
disputes. Adversary hearings, held on the record after notice and opportunity for participation by all interested parties, permit intensive examination of the factual assertions of the parties, particularly by the classic means of confrontation and cross-examination, and are plainly superior to ex parte proceedings in their capacity for ascertaining truth and reducing the possibility of error. ${ }^{30}$ This at least has been our faith, particularly when the protection of important interests has been at stake. ${ }^{31}$ That faith-based, too, on the desire that justice appear to have been done-has found expression in statutes requiring administrative hearings and in a steady line of judicial decisions requiring administrative agencies to provide adversary hearings with respect to a widening range of governmental actions. ${ }^{32}$

There is, however, no rule of constitutional law requiring in absolute terms that a constitutionally compelled hearing always be a prior hearing. Language in several Supreme Court decisions can arguably be read to suggest that whenever due process requires a hearing it requires a prior hearing: ${ }^{33}$ The context of that language, however, indicates that, almost certainly, it was not intended to carry such weight, and, in any event, the language is inconsistent with the holdings of a number of important decisions. ${ }^{34}$ Rather, what the Constitution does require, as Armstrong $v$. Manzo $0^{35}$ held, is that a constitutionally compelled hearing "be granted at a meaningful time and in a meaningful manner,"36 a standard that counsels a prudential inquiry case-bycase. $^{37}$

30 For a full discussion of the values served by adversary hearings, see Kadish, Methodology and Criteria in Due Process Adjudication-A Survey and Criticism, 66 Yaxe L.J. 319 (1957).

31 See Fuentes v. Shevin, 407 U.S. 67 (1972); Joint Anti-Fascist Refugee Comm. v. McGrath, 341 U.S. 123, 160-84 (1951) (Frankfurter, J., concurring).

32 See, e.g., Jenkins v. McKeithen, 395 U.S. 411 (1969); Willner v. Committee on Character \& Fitness, 373 U.S. 96 (1963); Goldsmith v. Board of Tax Appeals, 270 U.S. 117 (1926); Londoner v. Denver, 210 U.S. 373 (1908); Dixon v. Alabama State Bd. of Educ., 294 F.2d 150 (5th Cir.), cert. denied, 368 U.S. 930 (1961).

33 See, e.g., Morgan v. United States, 304 U.S. 1, 18-19 (1938); Garfield v. United States ex rel. Goldsby, 211 U.S. 249, 262 (1908); cf. Londoner v. Denver, 210 U.S. 373, 385 (1908) (hearing required before taking action "irrevocably").

34 See, e.g., Bowles v. Willingham, 321 U.S. 503, 519-21 (1944); Yakus v. United States, 321 U.S. 414,436 (1944).

35380 U.S. 545 (1965).

86 Id. at 552.

37 The "meaningful time" standard also indicates some qualification of Chief Justice Stone's declaration that "[t]he demands of due process do not require a hearing, at the initial stage or at any particular point or at more than one point in an administrative proceeding so long as the requisite hearing is held before the final order becomes effective." Opp Cotton Mills, Inc. v. Administrator, 312 U.S. 126, 152 (1941). The Chief Justice's statement has usually been taken to mean that it is not of constitutional significance 
Although the constitutional requirement of a prior hearing is not absolute, it is no less clear that prior hearings have come to be regarded as the norm. Recently, in Bell v. Burson, ${ }^{38}$ Justice Brennan, speaking for a unanimous Court, asserted as "fundamental" that "except in emergency situations ... due process requires that when a State seeks to terminate an interest such as that here involved, it must afford 'notice and opportunity for hearing appropriate to the nature of the case' before the termination becomes effective."3o It is fair to say, therefore, that when the Constitution requires a hearing, an administrative agency may be authorized to act summarily in advance of that hearing only in "emergency situations" that are themselves constitutionally defined. The question, then, becomes what constitutes an "emergency situation" within the constitutional meaning of the term..$^{40}$

1. Protecting the National Security During Wartime. War is the clearest example of an emergency situation in the life of a nation. When the United States has faced the extremity of war, Congress has enacted laws providing for summary procedures in the regulation of significant areas of the economy, and the Supreme Court-perhaps mindful of Hamilton's ironic vision of "the most extraordinary spectacle which the world has yet seen-that of a nation incapacitated by its Constitution to prepare for defence"41_has sustained them.

Thus, in Stoehr v. Wallace, ${ }^{42}$ a case involving World War I legislation, the Court upheld the constitutional authority of Congress to permit the summary seizure of "property believed to be enemy-

whether the constitutionally required hearing is given at the administrative level, Brown v. United States, 367 F.2d 907 (10th Gir. 1966), cert. denied, 387 U.S. 917 (1967), or by de novo review in court, Lichter v. United States, 334 U.S. 742 (1948); Jordan v. American Eagle Fire Ins. Co., 169 F.2d 281 (D.C. Cir. 1948). See generally United States v. Mllinois Cent. Ry., 291 U.S. 457, 463 (1934); Hagar v. Reclamation Dist. No. 108, 111 U.S. 701, 708-11 (1884); I K. Davis, Administrative LaW Treatise § 7.10, at 448, 450 (1958) [hereinafter cited as ADMINISTRATTVE LAW TREATISE].

38402 U.S. 535 (1971).

39 Id. at 542 (emphasis in original); see O'Neil, Of Justice Delayed and Justice Denied: The Welfare Prior Hearing Cases, 1970 SuP. CT. REv. 161, 169.

40 Analogies to commonplace stages of the criminal process, such as the return of an indictment, Ewing v. Mytinger \& Casselberry, Inc., 339 U.S. 594, 599 (1950), or the denial of bail, Oestereich v. Selective Serv. Sys. Local Bd. No. 11, 393 U.S. 233, 250 n.10 (1968) (Stewart, J., dissenting), are misleading insofar as they suggest that "emergency situations" may be of an equally commonplace character. Cf. United States v. Harper, $335 \mathrm{~F}$. Supp. 904, 906 (D. Mass. 1971) (dictum), vacated as moot, 406 U.S. 940 (1972). Those analogies draw upon practices with distinctive historical roots, Jenkins v. McKeithen, 395 U.S. 411, 430 (1969); they are not helpful in assessing the constitutional meaning of words drawn from a different historical context.

41 The Federalist No. 25, at 156 (Modern Library ed. 1937) (A. Hamilton).

12255 U.S. 239 (1921); accord, Central Union Trust Co. v. Garvan, 254 U.S. 554 (1921). 
owned"43 so long as provision was made for an eventual hearing. The provision for a subsequent hearing was found constitutionally adequate because it reserved to the claimant the right to establish his claim at a full judicial hearing, "unembarrassed by the precedent executive determination." 44

A generation later, in Bowles $v$. Willingham, ${ }^{45}$ the Court considered the constitutionality of a provision in the Emergency Price Control Act of 1942 authorizing the Price Administrator to establish maximum rents by order and without a hearing. The Court rejected the constitutional challenge in strong terms:

Congress was dealing here with the exigencies of wartime conditions and the insistent demands of inflation control. . . . National security might not be able to afford the luxuries of litigation and the long delays which preliminary hearings traditionally have entailed.

... [W] the regulations or orders have been made effective it has done all that due process under the war emergency requires. ${ }^{46}$

One of the central considerations in the Court's reasoning was the fact that the 1942 Act allowed the landlord to seek a subsequent judicial determination of his claim. The Act, however, allowed the courts to review the Price Administrator's decision only for arbitrariness; ${ }^{47}$ it did not provide a plenary judicial hearing of the kind approved in Stoehr $v$. Wallace. Although the judicial review provided by the 1942 Act was thus more restricted than that available in earlier cases sustaining summary procedures, a fact that would seem relevant to the constitutional adequacy of the legislative scheme, ${ }^{48}$ the Court took no note of the distinction.

43 World War I statutes providing for summary seizure of property are collected in United States v. Pfitsch, 256 U.S. 547, 553 nn.1-2 (1921).

44255 U.S. at 246.

45321 U.S. 503 (1944).

46 Id. at 520-21; see Yakus v. United States, 321 U.S. 414, 442-43 (1944). Congress's concern that prior hearings might hamper the rent control program seems to have been borne out by subsequent developments: in the first four years of the program, landlords filed 1,340,955 petitions for rent adjustments, each seeking an individual determination. W. Gellhorn \& C. Byse, ADMinistrative LaW, Cases and Comments 495 n.7 (5th ed. 1970). In light of the volume of cases, the administrative appeals machinery made avail. able by OPA, and the opportunity for judicial review, the Court might well have held summary determination of maximum rents constitutional even in the absence of war. See Richardson v. Perales, 402 U.S. 389, 406 (1971); Amalgamated Meat Cutters Union v. Connally, 337 F. Supp. 737, 758 (D.D.C. 1971).

17 Emergency Price Control Act of 1942, ch. 26, \& 204(b), 56 Stat. 31, as amended, Act of June 30, 1944, ch. 325, § 107, 58 Stat. 639, 50 App. U.S.C. § 924(b) (Supp. IV, 1945).

48 See 1 ADMinistrative LAW TrEatise, supra note 37, \$ 7.10, at 450 (1958); of. Jennings v. Mahoney, 404 U.S. 25 (1971). 
That Congress has acted pursuant to the war power, the Supreme Court once said, "does not remove constitutional limitations safeguarding essential liberties." 49 But it inevitably conditions the attitude that the Court takes in deciding whether the balance that Congress has struck on an issue such as the substitution of summary for plenary administrative hearings is constitutional. ${ }^{50}$ In Stoehr and in Willingham, the Court doubtless realized that the exigencies of wartime conditions were bound to infect many summary seizures of property and many summary establishments of maximum rents with serious error, but it was not prepared to interfere with Congress's discharge of its responsibilities during a grave national emergency.

Perhaps one cannot expect a court to undertake a skeptical balancing of the gains and losses from the use of summary procedures when Congress and the President, answerable to history for preserving the safety of the nation, have deemed them necessary to the successful conduct of the war effort. This suggests that decisions of the Supreme Court sustaining the constitutionality of summary administrative procedures enacted pursuant to the war powers should not be taken to mean that the same result would follow in time of peace. Justice Holmes made the point with characteristic felicity: "A limit in time, to tide over a passing trouble, well may justify a law that could not be upheld as a permanent change." 11

2. Protecting the Federal Government's Revenues. The tax laws of the United States have long permitted the collection of the internal revenue by the summary administrative method of jeopardy assessments. ${ }^{52}$ Because the usual methods of tax assessment and collection are deliberate, the delay attendant to their use may sometimes result in frustration of the government's proper claim, particularly when a taxpayer is wasting or concealing his assets or otherwise engaging in

49 Home Bldg. \& Loan Ass'n v. Blaisdell, 290 U.S. 398, 426 (1934) (footnote omitted); cf. Freedman, Administrative Procedure and the Control of Foreign Direct Investment, 119 U. PA. L. REv. 1, 5-6, 24-27 (1970).

50 Legislation enacted under the war power "is executed in a time of patriotic fervor that makes moderation unpopular. And, worst of all, it is interpreted by the judges under the influence of the same passions and pressures." Woods v. Cloyd W. Miller Co,, 333 U.S. 138, 146 (1948) (Jackson, J., concurring).

51 Block v. Hirsh, 256 U.S. 135, 157 (1921); see Chastelton Corp. v. Sinclair, 264 U.S. 543 (1924); P. Woll, Administrative Law, The Informal Process 33 (1963); Schwartz, Procedural Due Process in Federal Administrative Law, 25 N.Y.U.L. REv. 552, 566 (1950).

52 The present provision permits the Commissioner to assess a deficiency against a taxpayer and make demand for payment whenever he "believes that the assessment or collection of a deficiency . . . will be jeopardized by delay . . . IN INr. REv. Cone of 1954, § 6861(a); see J. Ghommie, The LAw OF Federal Income TAXation $\$ 260$ (1968). 
fraud. ${ }^{53}$ The jeopardy assessment insures that if the government's claim is sustained, there will be assets from which it can be paid: unless the assessed taxpayer makes payment of the alleged deficiency or stays collection by filing a bond to insure payment, ${ }^{54}$ the government may proceed to collect the tax by distraint. ${ }^{55}$

The jeopardy assessment is a drastic remedy, capable of imposing hardships that might have been demonstrated, had a hearing been held, to be unnecessary or disproportionate to the apparent exigencies of the moment. In order to make a jeopardy assessment, the Commissioner need only "believe" that collection of the tax will be jeopardized by delay-a judgment not subject to judicial review. ${ }^{56}$ Yet a taxpayer whose assets are frozen because he is unable to furnish a bond ${ }^{57}$ may be disabled from carrying on his business and enjoying his ordinary style of life. The impact of a jeopardy assessment is intensified by the fact that the Commissioner often determines the amount of the assessment in haste ${ }^{58}$ and has a tendency to overassess in order to protect the government against all possible losses. ${ }^{59}$

By what reasoning does the Constitution permit the use of procedures that can have such harsh results? In the leading case of Phillips $v$. Commissioner, ${ }^{60}$ the Supreme Court sustained the constitutionality of summary tax collection procedures as both long-accepted and necessary. ${ }^{61}$ The Court's assertion, documented extensively in the margins

53 See B. BrtTker \& L. Stone, Federal Income Estate and Gift TaXation 935 (4th ed. 1972).

54 INT. REv. CODE OF 1954, § 6863(a).

$659 \mathrm{~J}$. Mertens, The Law of Federal Income Taxation $\$ 49.149$ (rev. ed. 1965). In certain circumstances, the taxpayer's property may be sold prior to a hearing on the merits of either the government's claim or the taxpayer's defenses. INT. REv. CoDE of 1954, $\S 6863(\mathrm{~b})(3)$.

E6 Brown-Wheeler Co., 21 B.T.A. 755 (1930); see Homan Mfg. Co. v. Long, 242 F.2d 645 (7th Cir. 1957). For an argument that the Commissioner's decision to make a jeopardy assessment should be subject to judicial review for abuse of discretion, see Kaminsky, Administrative Law and Judicial Review of Jeopardy Assessments Under the Internal Revenue Code, 14 TAx L. Rev. 545 (1959).

57 See Kimmel v. Tomlinson, 151 F. Supp. 901, 902 (S.D. Fla. 1957) (dictum); 9 J. MERTENs, supra note 55, $\$ 49.149$ n.61, at 236 . The right to file a bond to stay collection of a jeopardy assessment has been called an "ephemeral remedy" because few sureties will insure payment of a jeopardy assessment. Gould, Jeopardy Assessments: When They May $B e$ Levied and What to Do About Them, N.Y.U. 18TH INST. ON FED. TAX. 937, 944-45 (1960).

$589 \mathrm{~J}$. MERTENS, supra note $55, \S 49.144$, at 231.

59 B. BITTKER \& L. STONE, supra note 53, at 935 . The Commissioner may make an assessment in an amount greater than that stated in the notice of deficiency and abate an assessment "to the extent that he believes [it] to be excessive in amount." INT. REv. CODE OF 1954, \& 6861(c).

60283 U.S. 589 (1931).

$61 \mathrm{Id}$. at 595-97. 
of Justice Brandeis's opinion, that the government's right to use summary administrative procedures in the collection of tax revenues "has long been settled" and "consistently sustained" was not an overstatement: the constitutionality of such procedures was sustained as early as 1856 in Murray's Lessee v. Hoboken Land of Improvement Co. ${ }^{62}$ But while summary tax collection procedures may make legitimate claim to an historic standing, and the result in Phillips $v$. Commissioner may be explained in part by the Supreme Court's willingness to honor that claim, the Court sought to rely on more than the normative power of history. The result was plainly meant to rest in considerable part upon what the Court called "the need of the government promptly to secure its revenues." 63

The government's need to collect tax revenues promptly, even when coupled with an appeal to history, is not adequate to support the result the Court reached. The question is not whether such a governmental need exists and is significant. Rather, it is whether the governmental need is of a character and weight sufficient to justify in constitutional terms the severe injury that summary administrative procedures can impose upon the taxpayer. The Court did not undertake to answer that question. Instead, it simply observed that "[d]elay in the judicial determination of property rights is not uncommon where it is essential that governmental needs be immediately satisfied."64 Yet the cases cited by the Court to support this observation-cases involving hazards to the public health, wartime threats to national security, and the power of eminent domain-are not obviously apposite. Public health hazards and wartime threats to national security are among the most serious perils a society faces, while the power of eminent domain is itself the product of a special historical development. The fact that "only property rights" 65 may be involved-although that is hardly the most sympathetic characterization of the values asserted by the taxpayerdoes not distinguish summary tax collection procedures from others involving property rights in which summary process would not be constitutional. Nor would the fact that the taxpayer is allowed a subsequent judicial determination of his rights by itself usually justify

6259 U.S. (18 How.) 272 (1856); cf. United States v. Key, 397 U.S. 322, 324 (1970) (noting that the statute giving the federal government's claim for unpaid taxes priority in a Chapter X reorganization "has existed almost unchanged since 1797, and its historical roots reach back to the similar priority of the Crown in England, an aspect of the royal prerogative, founded upon a policy of protecting public revenues").

63283 U.S. at 596.

64 $I d$. at 597 .

65 Id. at 596. 
summary procedures, although it would doubtless be entitled to weight in a reasoned inquiry into the balance of competing claims. ${ }^{66}$

Perhaps after a more careful inquiry, marked by a systematic attempt to balance the government's need to act summarily against the impact that jeopardy assessments can have on taxpayers, the Court in Phillips would have reached the same result. The Court might have concluded, for example, that effective administration of a tax system in a nation this large depends upon a norm of voluntary and prompt payment by the overwhelming number of taxpayers, and that use of the jeopardy assessment is essential if that norm is to be fostered and maintained. On the other hand, the Court might have concluded that alternate methods of enforcement could achieve the same result without such drastic consequences for the taxpayer. ${ }^{67}$ In either event, a systematic inquiry would have exposed the reasoning that led to the result and thereby served better to illuminate the constitutional law of summary action. Perhaps summary procedures have become so traditional in the collection of tax revenues that their consistency with due process is not seen as presenting a difficult question. However, as Justice Holmes once commented: "Everywhere the basis of principle is tradition, to such an extent that we even are in danger of making the role of history more important than it is."'68.

3. Protecting the Public Against Economic Injury. When the government acts summarily in tax matters, it does so to protect its own position as collector of the internal revenue. Constitutional questions are presented as well when the government acts summarily to protect the public against imminent economic injury, as when the Federal Home Loan Bank Board, without notice or hearing, appoints a conservator to enter into possession of a bank ${ }^{69}$ whose management it believes to be "pursuing a course injurious to, and jeopardizing the interests of, its members, creditors and the public."7o

The arguments supporting a constitutional right to a prior hearing in these circumstances are straightforward. The Board's decision to

66 See Nickey v. Mississippi, 292 U.S. 393, 396 (1934): "It is [constitutionally] enough that all available defenses may be presented to a competent tribunal before exaction of the tax and before the command of the state to pay it becomes final and irrevocable." Cf. L. JafFe, Judicial Control of Administrative Action 383-84 (1965).

67 See Kimmel v. Tomlinson, 151 F. Supp. 901,902 (S.D. Fla. 1957).

68 O.W. Holmes, The Path of the Law, in Colrecred Legal PAPERs 191 (1920).

69 Home Owner's Loan Act of 1933 § 5(d), as amended, I2 U.S.C. § 1464(d) (1946).

70 Fahey v. Mallonee, 332 U.S. 245, 247 (1947). Illustrative state court decisions include Financial Indem. Co. v. Superior Court, 45 Cal. 2d 395, 289 P.2d 233 (1955), and State Sav. \& Commercial Bank v. Anderson, 165 Cal. 437, 132 P. 755 (1913), aff'd, 238 U.S. 611 (1915). 
appoint a conservator tenders factual issues-about the character and quality of the bank's management and the potential for harm to the banking public - of a kind that have traditionally required an adversary hearing for their resolution. ${ }^{\mathbf{7 1}}$ Moreover, the seizure of a bank and ouster of its management have such serious consequences for all concerned that a prior hearing might reasonably be required as an essential safeguard against error, especially since the Board's determination to appoint a conservator is not subject to an anticipatory injunction ${ }^{72}$ and may not be reviewed for abuse of discretion until an administrative hearing on the merits has been concluded. ${ }^{73}$

These arguments in favor of a constitutional right to a prior hearing, persuasive as they may be in other contexts, did not prevail in Fahey $v$. Mallonee, ${ }^{74}$ in which the Court held that the summary authority given to the Board in 1933 was constitutional "in the light of the history and customs of banking:" 75 Congress was obviously aware that incompetence and malfeasance in the administration of a bank could precipitate its collapse, which in turn could present grave dangers to a community. The solvency of perhaps scores of creditors and the life savings of tens of thousands of depositors could be destroyed by what the Court called "problems of insecurity and mismanagement."76 By empowering the Board to appoint a conservator when substantial questions of malfeasance or incompetence were raised about a bank's management, Congress sought to avert real and serious dangers.

In acting to protect the public interest against the threat of a bank's collapse, Congress also attempted to accommodate the banking community's interest in the continued functioning of the bank until final disposition of the charges. When the Federal Home Loan Bank Board

71 See 1 Administrative LAW Treatise, supra note 37, § 7.08, at 438.

72 Greater Del. Valley Fed. Sav. \& Loan Ass'n v. FHLBB, 262 F.2d 371 (3d Cir. 1958); Hykel v. Federal Sav. \& Loan Ins. Corp., 317 F. Supp. 382 (E.D. Pa. 1970).

73 Beacon Fed. Sav. \& Loan Ass'n v. FHLBB, 162 F. Supp. 350 (E.D. Wis. 1958), appeal dismissed, 266 F.2d 246 (7th Cir.), cert. denied, 361 U.S. 823 (1959).

74332 U.S. 245 (1947).

76 $I d$. at 254. The quoted phrase brings to mind the Court's reliance on tradition in Phillips v. Commissioner. See text and notes at notes 60-62 supra. The importance of long usage as a factor in the reasoning by which the constitutionality of summary action is upheld was made express in an earlier decision that sustained a summary procedure by which the state took custody of abandoned bank deposits: "The fact that a procedure is so old as to have become customary and well known in the community is of great weight in determining whether it conforms to due process, for "Not lightly vacated is the verdict of quiescent years." " Anderson Nat'1 Bank v. Luckett, 321 U.S. 233, 244 (1944), quoting from Coler v. Corn Exch. Bank, 250 N.Y. 136, 141, 164 N.E. 882, 884 (1928) (Cardozo, J.), aff'd, 280 U.S. 218 (1930); see First Nat'l Bank of Smithfield v. Saxon, 352 F.2d 267 (4th Gir. 1965).

76332 U.S. at 250. 
appoints a conservator, it does so not to put a banking institution out of business, but rather to permit it to continue in business under a management whose competence and honesty are free from doubt. As one court said, "this temporary supersession involves no liquidation, no alteration of existing interests, and no discontinuity in the business of the [bank], but only a substitution pendente lite of the Board's representative for the directors and officers of the [bank] in the control and management of its affairs." 77 Appointment of a conservator, although a "drastic procedure," may thus be the most appropriate way in which to protect the interests of both the public and the bank.

The question remains, however, why the administrative hearing on the issues of incompetence and malfeasance should not come before, rather than after, appointment of a conservator. The answer lies in the realities of the situation. The bank might well be insolvent long before a prior hearing could be concluded. ${ }^{78}$ If the hearing were held in private, depositors and creditors would continue to entrust their money to a bank that the federal authorities believed might be unable to meet its obligations. A prior hearing would thus be of small value. On the other hand, the delay and publicity that would accompany a public hearing could be fatal to preservation of the banking institution as a going business and destructive of the position of depositors and creditors for whose protection the Board is responsible. The summary action upheld in Fahey $v$. Mallonee was, therefore, truly a response to an emergency situation: appointment of a conservator can effectively protect the interests of depositors and creditors and of the banking institution only if it can be done summarily. ${ }^{79}$

4. Protecting the Public Health against Impure Foods and Drugs. Protection of the public health against the dangers posed by impure foods and drugs has in this century become a standard governmental function, and summary procedures have become one of the standard means by which to carry it out. In the early case of North American

77 Greater Del. Valley Fed. Sav. \& Loan Ass'n v. FHLBB, 262 F.2d 371, 374 (3d Cir. 1958).

78 This is doubtless what the Court had in mind when it referred to "the delicate nature of the institution and the impossibility of preserving credit during an investigaton." 332 U.S. at 253.

79 In the related context of summary suspension of a broker-dealer's exemption from the full registration requirements of the federal securities laws, the District of Columbia Circuit cited Fahey $v$. Mallonee for the proposition that summary action may be taken where the public harm from failure so to act will exceed the private harm that summary action may inflict. R.A. Holman \& Co. v. SEC, 299 F.2d 127, 131 (D.C. Gir.), cert. denied, 370 U.S. 911 (1962); see Halsey, Stuart \& Co. v. Public Serv. Comm'n, 212 Wis. 184, 198, 248 N.W. 458, 461 (1933). 
Cold Storage Co. v. Chicago, ${ }^{80}$ the Court sustained the constitutionality of an Illinois statute permitting health inspectors to enter cold storage houses and "forthwith seize, condemn and destroy any such putrid, decayed, poisoned and infected food, which any such inspector may find in and upon such premises." The decision relied heavily on the state's authority to abate a nuisance:

We are of opinion, however, that provision for a hearing before seizure and condemnation and destruction of food which is unwholesome and unfit for use, is not necessary. . . . Food that is in such a condition, if kept for sale or in danger of being sold, is in itself a nuisance, and a nuisance of the most dangerous kind, involving, as it does, the health, if not the lives, of persons who may eat it. ${ }^{81}$

The state clearly has a significant interest in protecting "the lives and health of its inhabitants," 82 and summary destruction of food unfit for human consumption is plainly an effective means of doing so. But what if the inspector errs, and orders the destruction of food that in fact is not unfit for human consumption? The Court in North American Cold Storage found that the possibility of such error did not affect the constitutionality of the statute because a party whose property was mistakenly destroyed could recover in an action at law. The adequacy of a subsequent remedy in damages was, however, questionable. As the cold storage company argued, when the state destroyed the food it had seized, it also destroyed the only possible evidence of wholesomeness. The difficult question, therefore, is not whether summary seizure is supportable as an emergency measure-surely it is when one considers the serious injury that putrid food can inflict on large numbers of persons-but whether summary destruction is warranted.

The problem created by summary destruction for an owner who asserts the fitness of his food could be avoided in some cases by requiring that, whenever possible, the food be preserved either until a hearing can be held or at least until the owner's experts can examine it. ${ }^{83}$ That procedure would protect the public health and, at the same time, preserve the property owner's right to make a meaningful presentation on the merits and to regain his property if successful. ${ }^{84}$ Given the possibil-

80211 U.S. 306 (1908).

81 Id. at 315 .

82 Id.

83 Indeed, in North American Cold Storage, the owner maintained that the condemned poultry would have continued in the same condition, if properly stored, for three months. Id. at 320 .

84 See J. Dickinson, Administrative Justice and the Supremacy of LAW IN The United STATES 255-56 (1927). The Court dismissed the company's argument that destruction was 
ity of thus accommodating both parties' interests, what emergency remained to justify the constitutionality of summary destruction?

The Court's response indicated its concern that preservation of the seized food, although less drastic than destruction, might also be less effective. The food might be tampered with or distributed to the public by accident or by intentional evasion. ${ }^{85}$ Therefore, as the Court concluded, the legislature might plausibly believe that preservation itself constituted a serious threat to public health. ${ }^{86}$ The Court in North American Cold Storage thus deferred to the legislature's judgment that, in the particular emergency confronting health inspectors, no remedy less drastic than destruction can be an effective means of protecting the public health. ${ }^{87}$

The degree to which the Court remains prepared to defer to legislative judgments authorizing summary action arguably concerned with public health is illustrated by the leading case of Ewing $v$. Mytinger is Casselberry, Inc. ${ }^{88}$ The Food and Drug Administration, with the approval of the Attorney General, had made eleven summary seizures ${ }^{89}$ of a food supplement that it believed to be misbranded. In sharp contrast to the state's rationale for acting summarily in North American Cold Storage, no claim was made that the product was dangerous or in

improper because decayed foods have value for certain purposes. 211 U.S. at 321. Federal legislation that authorizes the Secretary of Agriculture to detain for twenty days any meat or poultry product that he has reason to believe is misbranded or adulterated requires that he preserve the product pending in rem condemnation proceedings or other action. See Poultry Products Inspection Act \& 19, 21 U.S.G. \$ 467a (1970); Federal Meat Inspection Act § 402, 21 U.S.C. § 672 (1970).

85211 U.S. at 320.

$86 I d$.

87 Cf. Adams v. Milwaukee, 228 U.S. 572 (1913), sustaining the constitutionality of an ordinance providing for the summary destruction of milk brought into the city without having been tested for tuberculosis and other contagious diseases. The Court concluded that the legislature could properly believe that preservation of uninspected milk, until it could be inspected, was impractical, but it did so only after evaluating the alternatives itself. Similar demonstrations of the limited scope of extraordinary governmental action are often required, under various rhetorical formulae, even as courts are upholding the action. See, e.g., Miller v. Schoene, 276 U.S. 272, 278-79 (1928) ("the only practicable method of controlling the disease"); Anderson v. Dunn, 19 U.S. (6 Wheat.) 204, 231 (1821) ("least possible power adequate to the end proposed"); Tippett v. Maryland, 436 F.2d 1153, 1160 (4th Gir. 1971) (Sobeloff, J., concurring in part, would require "the least drastic departure" from constitutional norms); Miller v. Forton, 152 Mass. 540, 547, 26 N.E. 100, 102 (1891) (Holmes, J., would require "actual necessity").

88339 U.S. 594 (1950).

89 See Food, Drug, and Cosmetic Act § 304(a), 21 U.S.C. § 334(a) (Supp. III, 1950), as amended, 21 U.S.G. \& 334(a) (1970) (multiple seizures authorized on probable cause to believe "the misbranded article is dangerous to health, or that the labeling of the misbranded article is fraudulent, or would be in a material respect misleading to the injury or damage of the purchaser or consumer"). 
any way harmful to health; as the trial court found, it was "at worst, harmless"90 and would do the public no good. ${ }^{91}$

The distributor of the product, seeking to enjoin the seizures as unconstitutional, argued that no emergency existed to justify the hardship and destructive publicity caused by the multiple summary seizures. Although the Court recognized that multiple seizures "can cause irreparable damage to a business"92 and that the preparation in question "may be relatively innocuous," 93 it nevertheless sustained the constitutionality of the summary seizure provision:

[Congress] may conclude, as it did here, that public damage may result even from harmless articles if they are allowed to be sold as panaceas for man's ills. A requirement for a hearing, as a matter of constitutional right, does not arise merely because the danger of injury may be more apparent or immediate in the one case than in the other. For all we know, the most damage may come from misleading or fraudulent labels. That is a decision for Congress, not for us. ${ }^{94}$

Because the food supplement presented no apparent threat to the public health, the Court's readiness to sustain the constitutionality of summary seizure on public health grounds is difficult to accept. Nonetheless, the Court has continued to point to the decision as an example of an emergency situation in which summary action is permissible.95 In doing so, the Court may be looking to the consumer protection rather than the public health aspects of the case. On that basis, $M y$ tinger \& Casselberry can be thought to go beyond North American Cold Storage in the deference shown the legislature since, without analyzing the nature of the consumer protection emergency to which Congress might have been responding, the Court said that "[t]here is no constitutional reason why Congress in the interests of consumer protection may not extend [the] area"98 in which summary seizure may be taken. Because of the apparent casualness with which the result was reached, it may be incautious to impute to the decision the broad holding that this statement suggests.

90339 U.S. at 604 (Jackson, J., dissenting).

91 The supplement was described as "an encapsulated concentrate of alfalfa, water cress, parsley, and synthetic vitamins combined in a package with mineral tablets." 339 U.S. at 596.

92 Id, at 599. See also Lev, The Multiple Seizure Bludgeon, 5 Food Drug Cosm. L.J. 585 (1950).

93 Id. at 601 .

$84 I d$, at 600 .

95 See, e.g., Bell v. Burson, 402 U.S. 595, 545 n.5 (1971); Goldberg v. Kelly, 397 U.S. 254, 263 n.10 (1970).

86339 U.S. at 600 . 
The Court in Mytinger \& Casselberry did not indicate that the legislature is required to select the least drastic remedy consistent with an effective response to the emergency confronting it. But the decision should not be read to extend the constitutionally permissible scope of summary action. For as the Court noted, ${ }^{97}$ the Food, Drug, and Cosmetic Act authorizes summary seizure only with the approval of the Attorney General.98 The Court may well have been persuaded that, by building this procedural safeguard into the administrative process by which summary authority may be exercised, Congress had satisfied the requirements of due process. ${ }^{99}$

\section{Situations Not Justifying Summary Action}

The classic decisions sustaining the constitutionality of summary action suggest the significance that the Supreme Court has attached to legislative decisions that summary procedures are necessary for effective governmental action. In several recent decisions, however, the Court has shown its willingness to override a legislative decision authorizing summary procedures when the facts do not make out an "emergency" or "extraordinary" situation in the sense required by the Constitution.

The most important of these decisions is Goldberg $v$. Kelly, ${ }^{100}$ which held unconstitutional the summary termination or suspension of welfare benefits under the federally assisted program of Aid to Families with Dependent Children. Because the administrative scheme challenged in that case provided for a "fair hearing" after the termination of benefits, the question whether due process required a prior hearing was squarely presented.

The Court recognized at the outset the impact that summary termination of benefits has on an eligible recipient: "[t]ermination of aid pending resolution of a controversy over eligibility may deprive an eligible recipient of the very means by which to live while he waits. Since he lacks independent resources, his situation becomes immediately desperate." 101 The Court went on to find two other factors basic to its decision.

97 Id. at 599.

9821 U.S.C. § 337 (1946), as amended, 21 U.S.C. § 337 (1970); cf. Helco Prods. Co. v. McNutt, 137 F.2d 681 (D.C. Cir. 1943).

99 At least one court has held in similar circumstances that the subsequent judicial determination must arise from "a de novo proceeding in the district court rather than from some lesser process merely involving judicial review of the administrative determination." SEC v. Alan F. Hughes, Inc., 461 F.2d 974, 979 \& n.8 (2d Cir. 1972); Greenawalt, All or Nothing at All: The Defeat of Selective Conscientious Objection, 1971 SUP. CT. REv. 31, 43-14.

100397 U.S. 254 (1970); see Wheeler v. Montgomery, 397 U.S. 280 (1970).

$101 \mathrm{Id}$. at 264 (emphasis in original). 
First, in cases in which subsequent hearings were held, decisions to terminate benefits were reversed with great frequency-according to one study, in over half the cases. ${ }^{102}$ It may be that those persons who persevered to the conclusion of the hearing process were not a representative group. Nonetheless, the incidence of error was sufficiently high to warrant the Court's concern with the use of summary procedures, given "the welfare bureaucracy's difficulties in reaching correct decisions on eligibility."103

Second, very few decisions to terminate welfare payments-perhaps one percent-were, in fact, appealed to subsequent hearings. ${ }^{104}$ As the Court suggested, this may have been in part because the recipient's "need to concentrate upon finding the means for daily subsistence" after his benefits have been terminated "adversely affects his ability to seek redress from the welfare bureaucracy."105

In light of the sobering import of these figures-that posttermination hearings cannot be expected to protect eligible welfare recipients against erroneous terminations-what countervailing governmental interests could justify the use of summary action? The government's argument that summary action "conserves both the fisc and administrative time and energy" 100 was properly rejected. ${ }^{107}$ The government's interest in protecting its purse, although a legitimate one, is hardly

102 See Handler, Justice for the Welfare Recipient: Fair Hearings in AFDC-The Wisconsin Experience, 43 SOC. SERv. Rev. 12, 22 (1969); cf. Richardson v. Wright, 405 U.S. 208, 221 (1972) (Brennan, J., dissenting) (official figures of a similar magnitude for reversals of suspensions of disability benefits under the Social Security Act).

103397 U.S. at 264 n.12; see Comment, Eligibility Determinations in Public Assistance: Selected Problems and Proposals for Reform in Pennsylvania, 115 U. PA. L. REv. 1307, 1926-27 (1967).

104 Bell \& Norvell, Texas Welfare Appeals: The Hidden Right, 46 TEx. L. REv. 223, 233 (1967); Burrus \& Fessler, Constitutional Due Process Hearing Requirements in the Administration of Public Assistance: The District of Columbia Experience, 16 AM. U.L. REv. 199, 213 (1967); Handler, supra note 102, at 20; Note, Withdrawal of Public Welfare: The Right to a Prior Hearing, 76 YALE L.J. 1234, 1244 (1967).

105397 U.S. at 264; see O'Neil, supra note 39, at 172. In addition, "[t] recipient may be illiterate; he may not understand how to obtain a hearing; he may regard welfare as charity and not realize that it may be asserted as a right; he may believe that requesting a hearing would damage his interests by angering the social worker, or he may be afraid to attend the hearing." Comment, The Constitutional Minimum for the Termination of Welfare Benefits: The Need for and Requirements of a Prior Hearing. 68 MICH. L. REv. 112, 130-31 (1969); see Briar, Welfare From Below: Recipients' Views of the Public Welfare System, 54 CaLIF. L. Rev. 370 (1966); Handler \& Hollingsworth, Stigma, Privacy and Other Attitudes of Welfare Recipients, 22 STAN. L. REv. 1 (1969).

108397 U.S. at 265.

$107 \mathrm{Id}$. at 266. For a suggestion that the Court rejected the state's argument too quickly, without adequately considering the costs that pretermination hearings would impose upon state welfare administrations, see The Supreme Court, 1969 Term, 84 HARv. L. REv. 30, 104-05 (1970). 
comparable to those that the Court has found adequate to sustain summary action in the true emergency cases. The payment of welfare benefits to persons subsequently found ineligible threatens no harm to the public health or safety or to national security, inflicts no economic injury on a specific group, and does not compromise the performance of a vital governmental function. ${ }^{108}$ In addition, in a humane scheme of constitutional values, conservation of the government's resources surely is not entitled to as much weight as "the individual's overpowering need in this unique situation not to be wrongfully deprived of assistance"109 until a hearing can be completed, particularly when no adequate remedy exists to correct the high incidence of error in termination decisions. ${ }^{110}$ In these circumstances, the rule of Armstrong $v$. Manzo"11 that constitutionally required hearings must "be granted at a meaningful time and in a meaningful manner"112 could be met only by a pretermination hearing. ${ }^{113}$

In another significant decision, Sniadach v. Family Finance Corp., ${ }^{114}$

108 The state may constitutionally recoup welfare benefits improperly continued. Snell v. Wyman, 281 F. Supp. 853 (S.D.N.Y. 1968), aff'd, 393 U.S. 323 (1969).

109 Kelly v. Wyman, 294 F. Supp. 893, 901 (S.D.N.Y. 1968).

110 See Van Alstyne, The Demise of the Right-Privilege Distinction in Constitutional Law, 81 HARv. L. REv. 1439, 1454 (1968): "Although the right to some form of process may be absolute, the extent to which particular safeguards are available nonetheless varies according to the circumstances. Where the consequence of error is relatively insubstantial, protection against the risk of error through the use of elaborate quasi-judicial procedures is subject to a constitutional trade-off with the need for administrative and fiscal economy." See also Newman, The Process of Prescribing "Due Process," 49 Calif. $\mathrm{L}$. REv. 215, 228 (1961). A similar concern about the incidence of exror characterizes the Court's decisions limiting the use of summary procedures in the regulation of obscenity. Blount v. Rizzi, 400 U.S. 410 (1971); Freedman v. Maryland, 380 U.S. 51 (1965); A Quantity of Copies of Books v. Kansas, 378 U.S. 205 (1964); see Note, Prior Adversary Hearings on the Question of Obscenity, 70 Colum. L. REv. 1403, 1415 (1970); Note, Postal Sanctions: A Study of the Summary Use of Administrative Power, 31 IND. L.J. 257 (1956).

111380 U.S. 545 (1965).

$112 I d$. at 552.

113 The Court sought to buttress its holding by reference to the social goals that animate the public assistance system. 397 U.S. at 265. Achievement of those goals-providing opportunities to the poor, avoiding the consequences of widespread frustration and insecurity-depends not only on termination procedures but also on the procedures by which initial eligibility is established. The Court, however, did not consider the possibility raised by Justice Black that if pretermination hearings are required, "the government will not put a claimant on the rolls initially until it has made an exhaustive investigation to determine his eligibility," thereby "insur[ing] that many will never get on the rolls, or at least that they will remain destitute during the lengthy proceedings followed to determine eligibility." $I d$. at 279 (dissenting). The Chief Justice and Justice Stewart also dissented. See Sparer, The Right to Welfare, in The Rughts of AmEricans 66, 74 (N. Dorsen ed. 1971).

114395 U.S. 337 (1969). 
the Court held Wisconsin's summary garnishment procedure unconstitutional because it did not provide a hearing prior to the in rem seizure of an individual's wages. Wages, the Court said, are "a specialized type of property," 115 distinctive in the hardship that their deprivation can cause. Thus, the Court implicitly recognized that prejudgment garnishment inflicts social costs similar to those that, in Goldberg $v$. Kelly, it found imposed by termination of welfare benefits.

The factors that the Court weighed in Sniadach and in Goldberg are similar in other respects. The likelihood that a creditor had garnished the wages erroneously or fraudulently and could not sustain his position at a judicial hearing was high. ${ }^{116}$ Moreover, once a person's wages are garnished, he is typically disabled from persevering to an eventual hearing on the merits. ${ }^{117}$ These two characteristics, like their analogues in Goldberg, suggest that a subsequent judicial hearing is not an effective protection for the wage earner against a garnishment that he could defeat on the merits-if he were able to persevere until a hearing.

In Goldberg the Court did not doubt that the state's asserted fiscal interest was a legitimate one, but found that it was not of sufficient weight to justify the injury inflicted by summary termination of welfare benefits. In Sniadach the Court found no state interest that rose to the level of the "extraordinary situations"118 that it said had existed in earlier decisions sustaining the constitutionality of summary action: the state had merely made available to creditors a procedural device giving their private interest an advantage over that of their alleged debtors. ${ }^{119}$ It would be hazardous to assert that state protection of a private interest is never entitled to the same degree of constitutional respect as state protection of a government interest-there is an obvious state interest in protecting important private interests. In Sniadach,

116 Id. at 340; see James v. Strange, 407 U.S. 128, 135-36 (1972); of. INT. REv. CodE of $1954, \S 6331$ (d).

116 See 395 U.S. at 341, quoting from 114 CoNG. Rec. 1832 (1968) (remarks of Representative Sullivan): "What we know from our study of this problem is that in a vast number of cases the debt is a fraudulent one, saddled on a poor ignorant person who is trapped in an easy credit nightmare, in which he is charged double for something he could not pay for even if the proper price was called for, and then hounded into giving up his pound of flesh, and being fired besides."

117 See Stanley v. Illinois, 405 U.S. 645, 657 (1972); 395 U.S. at 341, quoting from Com. ment, Wage Garnishment in Washington-an Empirical Study, 43 Wash. L. Rev. 743, 753 (1968).

118395 U.S. at 339; see id. at 343 n.* (Harlan, J., concurring).

110 Although the impact of a jeopardy assessment may be as severe as the impact of a garnishment, it is doubtful whether Sniadach undermines the constitutionality of the jeopardy assessment, which rests on the more substantial state interest it serves. Kennedy, Due Process Limitations on Creditors' Remedies: Some Reflections on Sniadach v. Family Finance Corp., 19 AM. U.L. REv. 158, 165-66 (1970). 
however, the state made no attempt to justify the importance of the particular private interest protected by the summary garnishment procedure at issue. ${ }^{120}$

The concerns that motivated the Court in Goldberg and Sniadach appear again in two later decisions. In Wisconsin v. Constantineau ${ }^{121}$ the Court held unconstitutional a state statute authorizing certain persons to post a public notice in retail liquor outlets prohibiting the sale or gift of liquor to named individuals with excessive drinking habits. Despite the "degrading" impact that posting might have on an individual, ${ }^{122}$ there was no provision in the law for notice or prior hearing. The statute gave the power of posting to a wide array of persons, including "the wife of such person" and a number of minor local officials. ${ }^{123}$ It is not surprising, therefore, that the Court was concerned that a posted individual "may have been the victim of an official's caprice," 124 especially since injury to reputation by error, as the melancholy history of defamation litigation suggests, is never wholly reversible.

In Bell $v$. Burson $^{125}$ the Court again applied the principles of Goldberg and Sniadach, holding unconstitutional a state statute requiring summary suspension of the driver's license of any uninsured motorist who was unable after an accident to post security for the amount of damages claimed against him. The Court found that the statute's failure to provide for a prior determination "whether there is a reasonable possibility of a judgment being rendered against [the motorist] as a result of the accident"126 was a denial of due process. The

120 Lower court interpretations of Goldberg and Sniadach have varied widely as a result. See Fuentes v. Shevin, 407 U.S. 67, 72 n.5 (1972); Comment, The Growth of Procedural Due Process Into a New Substance: An Expanding Protection for Personal Liberty and a "Specialized Type of Property ... in Our Economic System", 66 Nw. U.L. REv. 502 (1971).

121400 U.S. 433 (1971).

122 Cf. Cafeteria Workers Local 473 v. McEIroy, 367 U.S. 886, 898-99 (1961); Wieman v. Updegraff, 344 U.S. 183 (1952); Joint Anti-Fascist Refugee Comm. v. McGrath, 341 U.S. 123, 168 (1951) (Frankfurter, J., concurring).

123400 U.S. at $434-35$ n.2.

$124 \mathrm{Id}$. at 437 . A statute that lodges the authority to initiate summary action in relatively minor officials, as in Constantineau, or in private citizens, as in both Constantineat and Sniadach, greatly increases the likelihood of its ill-considered use. An administrative agency exercising summary authority is more likely to be cognizant of the legal implications of acting summarily, is more likely to have an informed basis for action, and is more likely to be compelled by its limited resources to restrict its use of summary action to the most egregious instances. Cf. Fuentes v. Shevin, 407 U.S. 67, 93 (1972) ("No state official participates in the decision to seek a writ [of replevin] ...."); Wellford $v$. Hardin, 444 F.2d 21, 25 (4th Cir. 1971).

125402 U.S. 535 (1971).

$120 \mathrm{Id}$. at 542 . 
Court assigned great weight, as it had in Goldberg, Sniadach, and Constantineau, to the impact of summary action on the individual. Bell, a clergyman whose ministry required him to travel by car to cover three rural Georgia communities, was "severely handicapped in the performance of his ministerial duties by a suspension of his licenses."127 Moreover, the likelihood of error meant, as it had in the earlier cases, that the impact would be entirely unjustified in some instances. ${ }^{128}$

The ultimate question in Burson was the nature of the governmental interest justifying the use of summary authority in the suspension of drivers' licenses. The Court found that "the only purpose" of summary suspension was to help private individuals to secure any judgment they might recover from the uninsured motorist. It may well be that such a use of summary authority serves a legitimate governmental purpose, especially since accident victims who do not receive compensation from those who have caused their injuries may require public assistance. But the legitimacy of the government's interest does not necessarily justify protecting it by summary action. If there was, in Burson, an emergency necessitating summary action, the state made no attempt to demonstrate it.

The decisions in these four cases-Goldberg $v$. Kelly, Sniadach $v$. Family Finance Corp., Wisconsin v. Constantineau, and Bell v. Burson -indicate that the Supreme Court is prepared, after weighing certain factors, to override a legislative determination that summary action is necessary or permissible. The factors to be considered include the severity of the impact of summary action on the individual's means for survival, his livelihood, and his reputation; the likelihood that the summary action will be taken erroneously; the degree to which it will disable the individual from participating in a subsequent hearing; and the adequacy of the subsequent hearing to protect his interests.

It may be suggested that these decisions are primarily a special response to poverty, and do not illuminate generally the constitutional law of summary action. There is no question that in Goldberg, Sniadach, and perhaps Bell, poverty served to intensify the impact of summary action on the individual. In each case, however, the state had the opportunity to demonstrate a countervailing governmental interest adequate to justify that impact. Indeed, the significance of these decisions lies in the states' inability to persuade the Court that such an interest existed.

128 The state made no inquiry into whether the licensee was at fault, even though liability could be imposed only for fault. 


\section{Conclusion}

Although summary action remains a striking exception to the due process requirement of a prior hearing, the Supreme Court has indicated that the state is justified in acting summarily, and hence does so without denying due process, when the state's interest in acting promptly to protect the public against a serious threat to its safety, health, or economic well-being outweighs the individual's interest in having an opportunity to be heard before the state acts, perhaps in error, in ways that may cause him significant injury. The Court has sustained the traditional uses of summary action in areas of longstanding governmental primacy-the waging of war, tax collection, the regulation of banking, and protection of the public health-because of the authenticity and urgency of the state's interest in meeting an emergency. Yet few of these decisions attempt to define an emergency by careful analysis of the facts that were before the legislature or the administrative agency.

More difficult cases-in which the gravity of the state's interest was less convincing and the impact of summary action on the individual more obvious-have made greater intellectual demands on the Court and caused it to refine its approach to the balancing process. These cases have arisen in contexts, such as the termination of welfare payments, quite removed from traditional areas of summary governmental action. The Court in these cases has examined factual situations skeptically and intensively, inquiring into both the precise nature of the state's asserted interest in acting summarily and the impact of summary process on the individual. As the state's interest in summary action has become more attenuated and the severity of its impact correspondingly less justifiable, the Court has declined to defer to particular legislative judgments. Rather, it has enforced stricter constitutional requirements as to what properly constitutes an "emergency" or "extraordinary" situation warranting the use of summary procedures.

\section{Summary Action as an Administrative Process:} Performance and Proposals for Improvement

The Supreme Court's decisions illuminating the theory of summary action and the constitutional principles to which it is subject are clearly important. But the process of government by which summary action is authorized and invoked depends on more than the decisions of the Supreme Court. It is the responsibility of the legislature in the first instance to determine whether to authorize an administrative agency to act summarily. The courts' insistence on statutory authoriza- 
$\operatorname{tion}^{120}$ seeks to insure that the legislature will authorize divergence from the constitutional norm of a prior hearing only after it has considered the implications of doing so.

The question whether Congress should authorize an administrative agency to act summarily-on what terms and under what restrictions -is thus a prudential one. A prior administrative hearing has become the constitutional norm because of the fundamental values that deliberative hearings are believed to serve: reducing the possibility of error and protecting the individual against precipitate use of governmental authority. ${ }^{130}$ When Congress grants an administrative agency the power to act summarily, it subordinates these values to others deemed more important.

What considerations should Congress take into account when it makes so significant a judgment? The inquiry is perhaps best approached by exploring how summary action works in practice, how administrative procedures might be structured to insure careful exercise of summary authority, and what role judicial review can play in tempering the impact of summary action.

\section{A. How Summary Action Works in Practice}

1. The Risk of Error. Summary authority is designed to be exercised in emergency situations. To be effective, it must often be exercised quickly, under the pressures of the moment. When an administrative agency acts in such exigent circumstances, it is likely to be acting upon incomplete information. Even when an agency has several weeks, or even months, to decide whether to act, as agencies empowered to suspend proposed rates usually do, the decision to take summary action is not always based upon adequate information. ${ }^{131}$

When an administrative agency acts on incomplete information, untested by the adversary process and untempered by an opportunity for deliberation, it is far more likely to err. The bounds of the resulting error may be extended by an agency's tendency-perhaps a proper one in the premises of an emergency - to insure that the public interest is adequately protected by entering summary orders that prove, in retrospect, unnecessarily broad. The Commissioner of Internal Revenue's tendency to overassess in making jeopardy assessments ${ }^{132}$ and the Food

129 See text and notes at notes 23-26 supra.

130 See text and notes at notes 30-32 supra.

131 Moss v. CAB, 430 F.2d 891, 902 (D.C. Cir. 1970); see, e.g., Spritzer, Uses of the Summary Power to Suspend Rates: An Examination of Federal Regulatory Agency Practices, 120 U. PA. L. REv. 39, 56 (1971) (Suspension Board of the ICC).

132 See text and notes at notes 58-59 supra. 
and Drug Administration's practice of condemning entire shipments of goods on the basis of representative samples ${ }^{133}$ are familiar examples. ${ }^{134}$ More complete information and an opportunity for greater deliberation would undoubtedly result in more precisely calibrated orders.

In addition, the risk of arbitrary action is almost surely increased when an administrative agency is permitted to act without the moderating constraint that the prospect of a prior hearing typically imposes on administrative initiatives. ${ }^{135}$ The existence of this risk was the subject of Judge Pell's vigorous dissent in Nor-Am Agricultural Products, Inc. $v$. Hardin. ${ }^{136}$ A national news program had reported that three young children were "rendered virtually vegetables"137 as the result of mercury poisoning allegedly caused by a fungicide. The next morning, the Secretary of Agriculture summarily suspended the registration of the fungicide as an "economic poison"138 pending a hearing on its permanent cancellation. The district court enjoined the suspension preliminarily but the court of appeals ultimately reversed en banc, holding that the Secretary's action was not subject to judicial review.

Judge Pell's dissent argued that the Secretary's decision to take summary action, reached on the basis of no more than undocumented and uninvestigated allegations, ${ }^{139}$ exemplified the danger that emotional charges would increase the likelihood of administrative arbitrariness and error:

When a product has been used on the market for more than twenty years and is essential for agriculture and when there has been no other recorded incident that the use of the product has been detrimental to the public health, I can reach no conclusion other than

133 See United States v. 431/2 Gross Rubber Prophylactics, 65 F. Supp. 534 (D. Minn. 1946), aff'd sub nom., Gellman v. United States, 159 F.2d 881 (8th Cir. 1947); A.O. Anderson \& Co. v. United States, 284 F. 542 (9th Cir. 1922).

134 Administrative regulations that attempt to ensure adequate protection for the public interest may also result in unnecessarily broad summary orders. See, e.g., SEC Rule 252(e)(2), 17 C.F.R. § 230.252(e)(2) (1971), requiring suspension of a broker-dealer's exemption from full registration with respect to all current offerings whenever it is suspended with respect to a single offering.

135 See Cramton, Some Modest Suggestions for Improving Public Utility Rate Proceedings, 51 IowA L. REv. 267, 274 (1966).

130435 F.2d 1151, 1161, rev'g on rehearing en banc 435 F.2d 1133 (7th Cir. 1970), petition for cert. dismissed, 402 U.S. 935 (1971).

137 Id. at 1162. See generally B. Roueche, The ORANGe MAN 116-37 (1971).

138 See Federal Insecticide, Fungicide, and Rodenticide Act $\S 4(\mathrm{c}), 7$ U.S.C. $\S 135 \mathrm{~b}(\mathrm{c})$ (1970).

138 See 435 F.2d at 1164; 46 IND. L.J. 238, 240 (1971). 
that the suspension was, in a technical and legal sense, an arbitrary and capricious one. ${ }^{140}$

The most deliberative administrative action may, of course, prove erroneous or arbitrary. The relevant question is the extent to which summary action results in a higher incidence of error than that resulting from formal adjudication. The few studies of summary termination of welfare payments undertaken prior to Goldberg $v$. Kelly found a disturbingly high incidence. ${ }^{141}$ In the absence of judicial review of summary action, however, empirical studies are possible only when a formal adjudicatory hearing is held after summary action has been taken, and such subsequent hearings are relatively infrequent. ${ }^{142}$ For example, more than 80 percent of the proposed tariffs summarily suspended by the Interstate Commerce Commission and more than 90 percent of those suspended by the Civil Aeronautics Board are either voluntarily withdrawn by the filing carrier or cancelled because of the carrier's failure to defend at a hearing. ${ }^{143}$ The percentage of summary seizures made by the Food and Drug Administration that are never contested at a subsequent hearing is almost certainly as high. ${ }^{144}$

Although it is difficult to measure the incidence of error accompanying summary action, the hypothesis that summary action results in a higher incidence of error than formal adjudicatory hearings remains convincing. The infrequency with which those affected by summary action contest its merits at a subsequent hearing does not obviously make the hypothesis less plausible. It does not necessarily indicate that those affected by summary action are prepared to concede the correctness of the agency's judgment; rather, it more likely suggests that the costs of contesting, in terms of resources, adverse publicity, and agency disfavor, are often prohibitive. ${ }^{145}$ In deciding whether to grant

140 Id. at 1161-62; see Stearns Elec. Paste Co. v. EPA, 461 F.2d 293, 308-09 (7th Cir. 1972).

141 See text and notes at notes 102-103 supra.

142 For an example where routine judicial involvement did make empirical study possible, see W. GELLHORN \& C. BYSE, supra note 46, at 529: "In a surprisingly large percentage of these cases [in which courts issued preliminary injunctions pending an administrative hearing], the NLRB found upon further investigation and hearing, that the complaint against the union was not sustainable; the conduct that had been enjoined was determined to be permissible after all."

143 Spritzer, supra note 131, at 53, 57 \& 76.

144 Telephone interview with William Conway, Assistant to the Regional Director, Food and Drug Administration, in Philadelphia, Apr., 1971.

145 Cf. 1 Administrative Law Treatise, supra note 37, $\$ 4.06$ (1958). But cf. R. Cramton, The Conduct of Rate Proceedings in the Interstate Commerce Commission 47 (Prelim. Draft, Dec. 1, 1961) (Report for the Administrative Conference of the United States). 
summary authority to a particular agency, Congress should therefore determine in each case whether the higher incidence of uncorrected error likely to result is acceptable in light of that agency's responsibilities.

2. The Role of the Staff. Commentators have long been concerned with the significant role that an agency's staff ${ }^{146}$ plays in the determination of administrative proceedings. ${ }^{147}$ The staff's role is accentuated when informal administrative decisions, such as the determination to invoke summary authority, are made. The staff's power to decide which matters to put to the members of the agency is itself of considerable significance. And once the staff elects to put a particular matter, the pressures of time and events that almost always surround a decision whether to act summarily make independent consideration by the agency's members difficult. They must inevitably rely heavily on the staff-to investigate the facts, to create a record, to assess the seriousness of the threat to the public, to analyze the likely consequences of acting or declining to act summarily, to give legal advice, and to recommend what action should be taken. ${ }^{148}$ These circumstances give the staff's recommendation an especial momentum for acceptance. ${ }^{149}$

The Hoover Commission noted the possibility that the staff may "extend or curtail the policies" of an agency in informal matters; it pointed to claims that the staff of the Securities and Exchange Commission, in enforcing the agency's registration requirements, "has insisted on more onerous requirements for disclosure than the Commission would demand." 150 Others have argued that years of enforcement effort unconsciously bias the staff, and that the staff is often permitted to enforce its bias without adequate supervision or correction by the members of the agency. ${ }^{151}$

146 See, e.g., A. Downs, Insme Bureaucracy 153-56 (1967); Johnson, Book Review, 23 SrAN. L. REv. 173, 184 (1970) ("It is axiomatic that an administrative agency's staff has substantial power in channeling and influencing the agency's actions.").

147 See, e.g., 2 Administrative Law Treatise, supra note 37, § 11; Beelar, The Dark Phase of Agency Litigation, 12 AD. L. BuLc. 34 (1959); Westwood, The Davis Treatise: Meaning to the Practitioner, 43 MINN. L. REv. 607, 614-17 (1967).

148 Freeman, Administrative Procedures, 22 Bus. LAw. 891, 894 (1967); Hector, Problems of the CAB and the Independent Regulatory Commissions, 69 YALE L.J. 931, 937 (1960).

149 At the Interstate Commerce Commission, the reality of the staff's preponderant role in the determination of whether to act summarily has been formalized: the Commissioners have delegated to a board of five employees the authority to decide initially whether to suspend proposed tariffs, subject to review by a division of the Commission. 26 Fed. Reg. 5167 (1961).

150 Commission on Organization of the Executive Branch of the Government, The INDEPENDENT REGULATORY COMMISSIONS 146 (1949) (Appendix N).

151 See Freeman, supra note 148, at 894; Lev, supra note 92, at 539. 
It would be surprising if an agency's staff, as a result of its investigation in a particular case, did not become convinced of the desirability of taking decisive administrative action. Indeed, because of its professional dedication and its regular exposure to an industry's marginal conduct, the staff may well become increasingly less sensitive to the individual problems of those whom the agency regulates and develop a propensity for strong regulation. It may believe that its proper role is to recommend that the agency act in borderline cases in order to encourage a toughened regulatory stance and to expose the members of the agency to the difficulties of controlling conduct at the extremity of its regulatory authority. The consequence may be that the members of the agency will approve staff recommendations that the staff thought would be rejected.

Care must be exercised, however, in drawing conclusions from these observations. Agency members are likely to be more sensitive than the staff to the unfavorable repercussions that can result from the injudicious use of summary power. Moreover, they are usually aware of the staff's desire to exert influence and its possible bias in pressing its recommendations. The Securities and Exchange Commission, for example, has established "administrative safeguards against over-zealousness by individual staff members."152 The Commission requires the staff to submit a memorandum as detailed as possible whenever it recommends that summary action be taken; if time does not permit, the agency members may be apprised of the basis for the staff's recommendation by an oral presentation, but the staff must submit a memorandum supporting its recommendation as soon as possible thereafter. Similarly, the Internal Revenue Service has designed an elaborate system of internal administrative review, including a progression of audits at the regional and national levels, to guard against unreasonable staff recommendations to make use of jeopardy assessments. ${ }^{163}$

Still, the question remains whether the staff is likely to have greater influence on decisions to exercise summary authority than it has on agency decisions made in the fullness of time. A categorical answer cannot be given because administrative agencies respond with varying degrees of urgency and success to the recurrently expressed concern

162 Address by Ralph H. Demmler, Chairman, Securities and Exchange Commission, Annual Meeting of the Section of Corporation, Banking and Business Law of the ABA, Aug. 17, 1954, in 10 Bus. LAw. 42, 46 (1954).

153 See Letter from William H. Smith, Deputy Commissioner, Internal Revenue Service, to Bernard Fensterwald, Jr., March 21, 1968, in Hearings Before the Subcomm. on Administrative Practice and Procedure of the Senate Comm. on the Judiciary, 90th Cong., 2d Sess. 73-75 (1968). 
that staff influence is too great. The concern, however, remains-it reflects tendencies that have been commented on for a generation and it corresponds with widely held views of how bureaucracies tend to make decisions under the pressure of time..$^{154}$

3. The Possibility of Prejudgment. Whenever the members of an agency participate in a decision to institute administrative proceedings, they run the risk-contemplated by the permissive provisions of the Administrative Procedure Act on commingling of functions ${ }^{155}$ - of becoming committed to a position on the merits. ${ }^{156}$ Philip Elman, reflecting on his service as a Federal Trade Commissioner, has said that "when Commission members, prior to issuing a complaint review investigative files for evidence of violations of the law, the burden of persuasion is subtly shifted to the respondent once the complaint does issue."157

In order to minimize the risk that members of an agency will become biased by participation in the decision to institute proceedings, many commentators have suggested that greater authority to act be delegated to the agency staff. ${ }^{158}$ Other commentators have been less alarmed by the risk; they have argued that the determination to issue a complaint "calls for mental activity like that involved in a judge's action on a demurrer or on an application for a temporary restraining order, and wholly unlike that involved in a prosecutor's efforts to compile an impressive record of convictions." 159 This argument may be valid with respect to the "mental activity" demanded in deciding to issue a complaint, but it does not deal adequately with the peculiar impetus to partiality that a decision to authorize summary action may create.

The decision to act summarily differs from other decisions to institute administrative proceedings. Because it typically has immediate and severe consequences for the respondent, the decision is quite properly

154 See generally M. Dimock, G. Dimock \& L. Koenig, Public Administration 150-69 (rev. ed. 1958); F. MarX, The Administrative State: AN Introduction to Bureaucracy (1957).

1555 U.S.C. $\$ \S 553-54$ (1970); see Freedman, supra note 49 , at 35-67.

156 "[F]or commissioners, as for judges," Judge Friendly has written, "freedom of decision is at least subconsciously constricted once a position has been publicly taken." Davis \& Randall, Inc. v. United States, 219 F. Supp. 673, 679 (W.D.N.Y. 1963) (footnote omitted). 157 Elman, Administrative Reform of the Federal Trade Commission, 59 GEo. L.J. 777, 810 (1971). But see Posner, The Behavior of Administrative Agencies, 1 J. LEgal Studies $305,333-36$ (1972).

158 See, e.g., Finax Report of the Attorney General's Comm. on Administratrve ProGedure, stipta note 1, at 22-23, 56-57; REPORT of THE ABA CoMmission to STUdy tHe Federal TRAde Commission 62-63, 82-84 (1969); Auerbach, The Federal Trade Commission: Internal Organization and Procedure, 48 MINN. L. REv. 383, 418-24 (1964).

159 W. GELLHORN \& C. BYSE, supra note 46 , at 878-79. 
exposed to closer public examination and the pressure on the agency to demonstrate the necessity and propriety of its action is increased. A decision in favor of the respondent at the ultimate hearing on the merits may be construed as an admission that the original action was arbitrary. The agency may therefore approach the hearing with a greater institutional self-interest in justifying its initial decision than it does in proceedings instituted by a complaint.

Even when self-interest of this kind does not affect the ultimate decision, the appearance of prejudgment is likely to remain. ${ }^{160}$ This situation may have serious consequences: it may place a cloud over the perceived fairness of the subsequent proceeding and may induce some respondents to forego their statutory right to a hearing. Both Congress and the agencies should therefore give careful thought to the development of means by which to avoid the possibility, as well as the appearance, that the decision to act summarily will influence the ultimate decision on the merits of the case, although the task is concededly difficult of achievement.

4. The Capacity to Injure Wrongfully. Summary action has a particular capacity to injure those against whom it is wrongfully invoked. In addition to its immediate effects, which may themselves be harsh, summary action often generates publicity that causes damage more enduring and extensive than do the terms of the summary order itself. When Secretary of Health, Education, and Welfare Flemming, two weeks before Thanksgiving in 1959, warned the public that a dangerous residue of pesticide chemicals remained on many cranberries in that year's crop, and the Food and Drug Administration summarily seized several shipments, substantially all of the crop remained unsold, although more than 99 percent of all the cranberries produced that year were subsequently found fit for consumption. ${ }^{161}$ Similarly, when the Securities and Exchange Commission summarily suspends trading in a security, the resulting publicity can destroy the marketability of the stock. ${ }^{162}$

160 See Gilligan, Will \& Co, v. SEC, 267 F.2d 461 (2d Cir.), cert. denied, 361 U.S. 896 (1959). In suspending a broker-dealer's registration pending a hearing on the merits of revoking it entirely, the SEC usually makes an express disclaimer of having predetermined the issue on the merits. See, e.g., Peerless-New York, Inc., 39 S.E.C. 712, 716 (1960).

161 Austern, Sanctions in Silhouette, Lecture at the Harvard Law School, March 22, 1960, quoted in W. Gellhorn \& C. BYSE, Administrative LAW, Gases and Comments 672 (4th ed. $1960)$.

162 See Note, Publicity and the Security Market: A Case Study, 7 U. CHr. L. REv. 676 (1940). The capacity to generate publicity damaging to an individual is one that summary action shares, of course, with ather forms of prehearing administrative action, particularly the issuance of press releases announcing the initiation of agency proceedings against an 
The capacity wrongfully to impose serious injury significantly distinguishes summary action from administrative action taken after a formal adjudicatory hearing. The damaging impact of summary action is a cause for particular concern because, in the absence of an administrative hearing, the risk of error is probably greater; the unfavorable publicity rests wholly on the agency's ex parte assertion; the order may be broader than necessary; and judicial review is typically unavailable. Moreover, the injury inflicted by summary action is sometimes so

individual. Gellhorn, The Treatment of Confidential Information by the Federal Trade Commission: Pretrial Practices, 36 U. CHI. L. REv. 113, 131-42 (1968); Rourke, Law Enforcement Through Publicity, 24 U. CHI. L. REv. 225, 231-38 (1957); Note, Disparaging Publicity by Federal Agencies, 67 CoLUM. L. REv. 1512 (1967).

The Commissioner of Internal Revenue, for example, has the capacity to inflict substantial damage upon an organization by use of a press release pending an administrative determination, as the Sierra Club found out in 1966. The Commissioner announced that the Service was instituting a proceeding to determine whether the club should be disqualified from receiving charitable contributions, deductible to the donor, because it had engaged in activities designed to influence legislation. Charitable contributions made to the Sierra Club after the date of the Commissioner's announcement would not be deductible if the Service ultimately concluded that the club was not a charitable organization for purposes of the Internal Revenue Code. That the Commissioner's press release severely hurt the Sierra Club cannot be doubted. "By issuing the press release, the IRS prevented the Sierra Club from wooing contributors with guaranteed deductibility during the investigation." Note, Problems and Procedures in Revoking the Eligibility of Charitable Organizations to Receive Deductible Contributions Because of Lobbying Activities-The Sierra Club Controversy, 55 CaLIF. L. REv. 618, 619 (1967). See also W. GELLHORN \& C. BYSE, supra note 46, at 522-23.

Because of the peculiar sensitivity of the securities market, the capacity of the Securities and Exchange Commission to cause substantial injury by announcing that a public proceeding will be commenced is perhaps as great as that of any federal agency. Kukatush Mining Corp. v. SEC, 309 F.2d 647 (D.C. Cir. 1962); Silver King Mines, Inc. v. Cohen, 261 F. Supp. 666 (D. Utah 1966); Note, Publicity and the Security Market: A Case Study, 7 U. Car. L. REv, 676 (1940). The Commission is authorized to issue a stop order suspending the effectiveness of a registration statement only after notice and hearing. Securities Act of $1933 \S 8(d), 15$ U.S.C. $\$ 77 \mathrm{~h}$ (d) (1970). But the very announcement that such a hearing will be held, usually given wide-spread publicity, can have, as one court has said, "grave consequences." Wolf Corp. v. SEC, 317 F.2d 139, 142 (D.C. Cir. 1962); see Jones v. SEC, 298 U.S. 1, 13 (1936); L. Jaffe \& N. Nathanson, Administrative Law, Cases and Materiats 20-21 (3d ed. 1968); J. LANDIS, supra note 13. Similarly, serious injury typically follows the public announcement that the Commission has given a broker-dealer notice of a hearing to suspend his registration pending a final determination at a hearing on revocation. Securities Exchange Act of 1934 \& 15(b)(6), 15 U.S.C. $\$ 78 o(b)(6)(1970)$. "The moment you bring a public proceeding against a broker-dealer who depends upon public confidence in his reputation," an experienced lawyer in this area has written, "he is to all intents and purposes out of business. His. business is destroyed before he has a chance to defend himself and before the Commision has had a chance to hear his side of the case and to decide whether he is guilty of the matters charged, or whether, in fact, he is innocent." Freeman, supra note 148, at 897. See also Silver v. New York Stock Exchange, 373 U.S. 341, 368 (1963) (Stewart, J., dissenting); FTC v. Ginderella Career \& Finishing Schools, Inc., 404 F.2d 1308 (D.C. Cir. 1968); Mason, Administrative Law-Reality or Red Tape?, 40 REv. Jur. U.P.R. 91, 100 n.20 (1971). 
great that, in effect, the availability of a subsequent hearing is meaningless. In Aquavella $v$. Richardson, ${ }^{103}$ the Secretary of Health, Education, and Welfare's summary suspension of medicare payments to a nursing home, which depended on them almost entirely for its revenue, "quickly forced [it] out of business." 184 For the businessman whose market has been wrongfully destroyed by a summary order, for the college student wrongfully expelled on the eve of graduation, the prospect of achieving ultimate vindication on the merits has only poetic appeal: the damage and disruption already imposed is irremediable.

In other instances, including many in which a favorable decision at a subsequent hearing would be meaningful, summary action has such a devastating impact that the affected party is disabled from effectively contesting the merits. Thus, as the Court noted in Goldberg v. Kelly, the termination of welfare benefits "adversely affects [a recipient's] ability to seek redress from the welfare bureaucracy." 105 As a consequence, the injury caused by wrongful invocation of summary authority may never be cured.

5. Increased Reliance on Informal Processes. The capacity of summary action to render a subsequent hearing meaningless or to disable an individual from participating in it effectively has important implications for an agency's relationship with those whom it regulates. Whenever the impact of summary action is likely to be severe, the power to threaten its invocation may be as significant as actually invoking it. The power of the Food and Drug Administration, for example, to threaten the seizure of goods is so great that the owner may acquiesce in the agency's objections even though he believes them unfounded.18s Exercise of a rate-regulating agency's power summarily to suspend proposed rates can have such costly consequences that a carrier may be prepared to consent to a specific rate structure whose approval has been foreshadowed by the agency simply because it cannot absorb the financial loss that suspension would impose. ${ }^{167}$

103437 F.2d 397 (2d Cir. 1971).

$164 I d$. at 404 .

165397 U.S. 254, 264 (1970); see Oestereich v. Selective Serv. Sys. Local Bd. No. 11, 393 U.S. 233 (1968).

166 See Developments in the Law-Deceptive Advertising, 80 HARv. L. REv. 1005, 1112-13 (1967). See also Comment, Governmental Enforcement Powers in the Regulation of the Drug Industry, 24 Sw. L.J. 500 (1970).

107 R. Caves, Arr Transport and Its Regulators 362 (1962); see Moss v. CAB, 430 F.2d 891 (D.C. Cir. 1970) ("the pressures on the carriers to file rates conforming exactly with the [CAB's] formula were great, if not actually irresistible," $i d$. at 897 , because they were faced with "immediate revenue needs . . . in times of rapidly rising costs," id. at 900). 
The power of the Federal Home Loan Bank Board to appoint a conservator is so momentous that few banks can resist the agency's recommendation that they sign proposed consent decrees agreeing to changes in challenged practices, even though the bank may be convinced that the practices are legal. ${ }^{168}$

The extent to which the mere availability of summary authority is sufficient to coerce compliance with an agency's demands, typically by means of an informal settlement, cannot readily be measured. But the existence of the phenomenon-what Commissioner Goddard of the Food and Drug Administration called "the somber gun of enforcement"169_can hardly be doubted. Indeed, it is sometimes argued that administrative agencies need credible reserves of power precisely because of their usefulness in encouraging informal settlements, without which effective regulation would be considerably more difficult to achieve. ${ }^{170}$

The power to act summarily is doubtless a forceful bargaining weapon in strengthening an agency's capacity to secure settlements: it lessens an individual's incentive to assert unrealistic positions and to employ delaying tactics. ${ }^{171}$ But when the powers possessed by the administrator are great, he may be inclined to take advantage of their coercive potential by demanding changes in behavior that, however much they conform to an enlightened conception of equity or justice, are beyond his statutory authority to exact. An administrator who can back his demands with the threat of summary action may also be tempted to seek concessions to which he would not be entitled on the evidence, were it fully developed at an adjudicatory hearing. Some commentators have charged, for example, that the Securities and Exchange Commission sometimes succumbs to these temptations in exercising its discretionary power to accelerate the effective date of a registration statement ${ }^{172}$ (which is requested by virtually every registrant). ${ }^{173}$ As

168 See K. Davis, Administrative Law, Cases-Text-Problems 76 (1965). In addition, an individual who is subject to an agency's continuing supervision may sometimes accede to an agency demand in the belief that too-frequent resistance may, in the long run, jeopardize his relationship with the agency. Handler, Controlling Official Behavior in Welfare Administration, 54 CALIF. L. Rev. 479, 494 (1966); Freedman, supra note 49, at 34.

1691967 HEW ANN. REP. 198.

170 See Massel, The Regulatory Process, 26 Law \& Contemp. Prob. 181, 187 (1961).

171 Cf. Fortas, The Securities Act and Corporate Reorganizations, 4 LAw \& ConTEMP. Proв. 218, 239 (1937). See generally Gellhorn \& Robinson, Summary Judgment in Administrative Adjudication, 84 HARv. L. REv. 612 (1971).

17217 C.F.R. § 230.460 (1971). See generally 4 L. Loss, Securities Regulation 2338-40 (2d ed. 1961, Supp. 1969).

173 See Wyoming-Gulf Sulphur Corp., 37 S.E.C. 367 (1956); Mulford, "Acceleration" Under the Securities Act of 1933-A Reply to the Securities and Exchange Commision, 
Professor Davis has noted, "Business reasons usually make acceleration ... so compelling that the registrant is willing to yield to onerous conditions,"174 particularly with respect to the extent of disclosure of information, even though he is convinced that a court would find that the Commission had exceeded its proper authority. Similarly, prior to Goldberg $v$. Kelly it was said that because of the power to terminate public assistance without a hearing, caseworkers were able to enforce standards of personal behavior that were not required by law. ${ }^{175}$

Whatever the validity of these particular objections, the inclination of an agency to seek informal settlements as a substitute for the use of summary authority is probably explained more by a reluctance to invoke such awesome powers than by a temptation to coerce illegitimate results. Indeed, this reluctance to risk imposing the severe injuries of which summary action is capable often leads an agency to devise mechanisms that eventually supplant summary action as the usual method for achieving the agency's legislative mandate. Examples of these mechanisms include the Food and Drug Administration's elaborate recall procedures, described in the regulations as "an alternative to multiple seizures"176 and regarded, in the words of Commissioner Goddard, as "less punitive"177 than summary action; the Federal Communications Commission's technique of "constant surveillance" in regulating the rates of common carriers; ${ }^{178}$ the Federal Home Loan Bank Board's reliance on consent orders to end questionable banking practices; ${ }^{179}$ and the "speaking" rate suspension order of the Civil Aeronautics Board, condemned in Moss $v$. CABB ${ }^{180}$ as subversive of the statutory scheme.

14 Bus. LAw. 156 (1958); Mulford, "Acceleration" Under the Securities Act of 1933-A Postscript, 22 Bus. LAw. 1087 (1967).

174 K. DAvis, supra note 168, at 73-74; cf., e.g., Wall Street Journal, Mar. 14, 1972, at 12, col. 3 (signatories to an SEC consent order said they "consented to sanctions because the proceedings would have required an enormous expenditure of time, effort and money .....").

175 See Handler, supra note 168, at 494-95; Sparer, The Role of the Welfare Client's Lawyer, 12 U.C.L.A.L. REv. 361, 367-71 (1965).

17621 C.F.R. § 3.85 (1972); see text at notes 189-91 infra.

1771967 HEW ANN. REP. 197.

178 See Public Util. Comm'n v. United States, 356 F.2d 236 (9th Cir.), cert. denied, 385 U.S. 816 (1966); Spritzer, supra note 131, at 62-75; Welch, Constant Surveillance: $A$ Modern Regulatory Tool, 8 ViL.. L. REv. 340 (1963).

179 Memorandum from Mary Jane Checchi, Staff Attorney, Administrative Conference of the United States, to James O. Freedman, Aug. 24, 1971, at 2 (copy on file at The University of Chicago Law Review); Letter from Tynan Smith, Secretary of the Board of Governors of the Federal Reserve System, to Richard K. Berg, Executive Secretary, Administrative Conference of the United States, Oct. 17, 1972 (on file at The University of Chicago Law Review).

180430 F.2d 891 (D.C. Cir. 1970). 
The consequence of administrative innovations such as these is that governmental challenges to private conduct are more often resolved informally than by the hearing processes that Congress provided as part of the legislative scheme authorizing summary action. This has serious implications for administrative regulation. When an agency prefers informal negotiations to the more formal process that moves from summary action to the conclusion of a subsequent evidentiary hearing, its actions are shielded from judicial review and public scrutiny alike. The technique of "constant surveillance," for example, may effectively exclude interested persons from participation in the regulatory process although they would have a right to be heard at formal proceedings.

If granting summary authority to an agency can thus lead to increased reliance on informal processes, then a responsible legislative decision to grant that authority cannot be made without considering whether this is a desirable result. Congress undoubtedly understood that administrative agencies would rely in some measure on informal processes, but it did provide for formal, more public procedures in areas made subject to summary action. The question in each instance, therefore, must be whether an agency has struck a proper balance between the use of summary action and the negotiation of informal settlements.

6. The Extent to Which Summary Action Is Used. The reasonableness of the use of summary power can be measured, in a rough way at least, by the frequency with which federal administrative agencies invoke their summary authority to perform a variety of regulatory tasks.

a. Of the six agencies for which data are available, the Internal Revenue Service has made the least use of its summary authority. During 1966 and 1967, the last two years for which statistics have been published, the Commissioner ordered, respectively, ninety-two and seventy-five jeopardy assessments for suspected income, estate, and gift tax deficiencies. ${ }^{181}$ Since more than 100 million tax returns were filed in each of the two years, ${ }^{182}$ and many of the jeopardy assessments ordered during those years related to returns filed in previous years, the Commissioner's use of jeopardy assessments in the administration of the tax laws has been strikingly limited.

b. The Securities and Exchange Commission has summary authority

181 Letter from William H. Smith, Deputy Commissioner, Internal Revenue Service, to Bernard Fensterwald, Jr., Mar. 21, 1968, in Hearings, supra note 153, at 76. But see Gould, supra note 57 (indicating that 2,500 jeopardy assessments were ordered in fiscal 1958).

1821966 IRS ANN. REP. 14; 1967 IRS ANN. REP. 16. 
to suspend trading in a registered security for a period not exceeding ten days when the public interest so requires. ${ }^{183}$ In the course of regulating trading in the tens of thousands of securities registered under the Securities Exchange Act of 1934, the SEG has increasingly (although still sparingly) used that authority. In 1970 , it suspended trading only fifty-five times; in the several years prior to 1970 , it did so even less frequently. ${ }^{184}$

The Commission has also made only limited use of its summary authority to suspend the exemption from registration granted issuers of certain small offerings when it believes the issuer is not entitled to the exemption or has violated one of its conditions. ${ }^{185}$ During the last three fiscal years for which information is available, the Commission suspended less than two percent of the outstanding exemptions, an average of twenty-two per year. ${ }^{186}$

c. During fiscal 1970, the Food and Drug Administration instituted 600 seizure proceedings involving adulterated or mislabeled foods, drugs, and cosmetics on the basis of information gained by conducting 27,275 inspections (of factories, warehouses, and public eating places) and collecting 61,298 product samples for testing. ${ }^{187}$ As it has for every year since fiscal 1968, the Food and Drug Administration thus resorted to summary action in less than one percent of the cases in which inspection or sampling had provided a basis for determining whether the law had been violated.

Although the number of seizures made by the FDA in each year since 1968 has been less than 750 (the average has been 600), more than 1,000 seizures were instituted in six of the seven years prior to 1968, with a high of 1,288 in fiscal 1964.188 The reduction in the number of seizures in recent years may reflect in part a reduction in the Food and Drug Administration's inspection and sampling activity. ${ }^{189}$ A more accurate explanation, however, can probably be found in the agency's 1965 decision to substitute voluntary recall procedures for summary seizure. ${ }^{100}$

183 Securities Exchange Act of $1934 \S \S 15(c)(5), 19(a)(4), 15$ U.S.C. $\S \S 78 o(c)(5), 78 s(a)(4)$ (1970).

184 1966-70 SEC ANN. REPS.

185 Securities Act of 1933 §§ 3(b), (c), 15 U.S.C. $\$ \S 77 \mathrm{c}(\mathrm{b})$, (c) (1970); 17 C.F.R. $\S \S 230.261$, 230.340, 230.610, 230.656 (1972).

186 1968-70 SEC ANN. REPS.

1871970 HEW ANN. REP. 273-74. The figures for the two preceding years are of the same order.

188 1961-70 HEW ANN. REPS.

189 The number of samples collected has declined every year since it peaked in 1964; inspections have declined less evenly from their peak in 1963. Id.

10021 C.F.R. \& 3.85 (1972); see 1965 HEW ANN. REP. 336-37. Before that decision, in 
d. The Federal Power Commission has summary authority to suspend proposed tariffs for up to five months pending a hearing and decision on their reasonableness. ${ }^{191}$ Figures compiled informally by the Commission indicate that in fiscal 1970 the Commission suspended only three of the 2,272 tariffs filed by electric utilities and 26 of the 1,320 tariffs filed by natural gas pipeline companies. ${ }^{192}$ These figures must be viewed with caution, however, because the Commission has apparently limited the use of its suspension power to tariffs proposing rate increases. If these tariffs are considered separately, the Commission has invoked its suspension authority in a very high incidence of natural gas pipeline cases, in some years exceeding seventy percent. ${ }^{193}$ Of the approximately twelve thousand tariff changes proposed by natural gas producers in 1970, more than 40 percent were suspended, largely pursuant to the Commission's policy of automatically suspending all proposed gas rates that exceed tentative ceilings established for each area. ${ }^{194}$

e. The Interstate Commerce Commission, exercising its summary authority to suspend proposed tariffs for seven months pending a hearing and decision on their reasonableness, typically suspends in full or in part approximately one to two percent of the tariffs filed annually. ${ }^{195}$ In fiscal 1970, for example, the Commission considered for suspension 11,137 -or 3.6 percent-of the 305,517 proposed tariffs filed. ${ }^{196}$ The tariffs considered for suspension represented 4,088 "tariff adjustments," 197 defined as any change in one or more tariffs raising a discrete issue. ${ }^{198}$ The Commission ultimately suspended 1,758, or less than half of the adjustments considered. ${ }^{199}$

f. The Secretary of Health, Education, and Welfare is authorized by section 225 of the Social Security Act to suspend payment of disability benefits if he believes that a recipient is no longer disabled. ${ }^{200}$ The

1964, over 92 percent of 1,398 removals from the market were seizures; however, of the 2,027 removals during 1970, less than 30 percent were accomplished by seizure and more than 70 percent by recall. See 1964 HEW ANN. REP. 291, 325; 1970 HEW ANN. REP. 273-74. 191 Federal Power Act § 205(e), 16 U.S.C. § 824d(e) (1970); Natural Gas Act § 4(e), 15 U.S.G. $\$ 717 c($ e) $(1970)$.

192 Spritzer, supra note 131 , at 107.

193 A comparable organization of data with respect to electric utility tariffs is not available.

194 See Permian Basin Area Rate Cases, 390 U.S. 747, 771 (1968).

195 1961-70 ICG ANN. REPS.

196 See Spritzer, supra note 131, at 106.

1971970 ICG ANN. REP. 41.

198 See P. Wor., supra note 51, at 85; Spritzer, supra note 131, at 51.

1991970 ICC ANN. REP. 41.

20042 U.S.C. $\S 425$ (1970). 
Department does not publish statistics indicating how frequently this authority has been used, but Justice Brennan, dissenting in Richardson $v$. Wright, ${ }^{201}$ noted that the Secretary had suspended disability benefits in 38,000 cases in 1971 , but he did not indicate the total number of persons receiving benefits that year. ${ }^{202}$

The statistics for these six agencies suggest, if any generalization is possible, that summary action has been taken by most agencies against only a small percentage of those whose activities are subject to their regulatory authority. The limited use of summary action by the federal administrative agencies is consistent with its exceptional position in our constitutional scheme.

The statistics do not, however, indicate whether summary authority has been used wisely. They do not provide a basis for determining whether summary authority has been used too much or too little or in the most appropriate cases. They do not indicate the degree to which an agency's decisions to take summary action vel non have been influenced or necessitated by the coercive power that the existence of summary authority can generate; by the availability of alternative, often informal, regulatory processes; by the size of the agency's budget; by the competence of its staff; and by the political power of the particular regulated industry.

If agencies compiled more complete statistics, the decision whether to invoke summary authority might be better understood, permitting Congress to initiate more detailed inquiries into the use of summary power and into the desirability of enlarging or restricting its applications. As a first step toward better informed legislative decision making, Congress should require agencies now invested with summary authority to publish statistics that indicate more completely the frequency and circumstances of its use.

\section{B. Structuring the Use of Summary Authority}

Lawyers have long understood as a general proposition what James Willard Hurst calls the substantive importance of procedure. But the relevance of procedure to informal administrative action has only recently begun to receive serious scholarly attention. ${ }^{203}$ It is necessary

201405 U.S. 208, 224 (1972).

202 The number of workers receiving disability benefits is not available, but, in fiscal 1970, 2.6 million workers and their dependents were recipients. See 1970 HEW ANN. REP. 280.

203 See, e.g., K. Davis, Discretionary Justice, A Preliminary Inquiry (1969); E. Gellhorn, AdMinistrative LAw ANd Process in a Nutshell 100-20 (1972); Gardner, The Procedures By Which Informal Action Is Taken, 24 AD. L. REv. 155 (1972); Lockhart, The Origin and Use of "Guidelines for the Study of Informal Action in Federal Agencies", 
to move tentatively, therefore, in considering whether procedures commonly used to structure formal administrative processes have appropriate application to the informal process of summary action. The extent to which a specific procedure can serve to increase the fairness of an agency's performance in acting summarily depends, of course, on whether it is adapted to the agency's particular responsibilities and circumstances. The task of Congress is to determine, after individualized inquiry, the specific procedures appropriate for a particular agency and whether such procedures should be imposed by legislation. The most appropriate response for Congress in many regulatory contexts may be to encourage agencies to devise their own procedures and to permit them to modify these procedures as experience recommends. Regardless of whether Congress acts, administrative agencies have a continuing responsibility to consider whether particular procedural devices would achieve greater fairness in the exercise of summary authority.

A number of requirements and procedures-some drawn from formal administrative processes, some suggested by the general features of summary action-are worthy of serious examination. They do not, of course, exhaust the possibilities.

1. Statutory Standards. One way in which Congress could structure the use of summary authority would be to enact statutory standards for its exercise. It would be possible to formulate standards in a variety of terms. They could follow the language of constitutional requirement appearing in Supreme Court decisions, for example, in order to stress the exceptional nature of summary action. They could borrow from the criteria that equity courts enforce in granting and denying preliminary injunctions. Or they could use new formulations defining the degree of exigency or emergency required, or the quantum of evidence that an agency must possess, before summary action can be taken. One such definition might provide that an agency can take summary action only if no less drastic means gives promise of being equally effective in achieving substantially the same result.

In framing statutory standards, the stringency of the requirements will necessarily vary from one agency to another, depending, for example, on the severity of the impact that the summary actions of each agency typically have. In addition, different evidentiary standards may be appropriate when an agency takes summary action on its own

24 AD. L. REv. 167 (1972); Sofaer, The Change-of-Status Adjudication: A Case Study of The Informal Agency Process, 1 J. Legal StUdIEs 349 (1972). 
initiative than when it does so in response to the request of an interested private citizen. ${ }^{204}$

Although Congress has not always undertaken to provide statutory standards for the exercise of summary authority, ${ }^{205}$ it has done so occasionally with apparent success. The Federal Insecticide, Fungicide, and Rodenticide Act, for example, provides that the Administrator of the Environmental Protection Agency may suspend the federal registration of an "economic poison" only if it presents "an imminent hazard to the public." 200 Although Congress chose language sufficiently precise to convey its intention that "this authority ... should only be exercised under the most extreme conditions and with the utmost care,"207 it also chose language sufficiently general to allow the Administrator to exercise discretion on issues of substantive significance: for example, whether a hazard may be considered "imminent" if its impact will not be felt for many years, and whether the preservation of fish and wildlife are among the interests of the "public" that the statute is designed to protect. $^{208}$

Because statutory standards for the exercise of summary authority will typically be framed in general terms, it may be argued that they will be regarded as no more than hortatory and will have little influence on the actual behavior of administrators. One cannot be certain that there is not some truth to this argument. Nonetheless, when Congress enacts a statute imposing standards, even general ones, on the exercise of administrative authority, it "expresse[s] a mood," as Justice Frankfurter wrote in a relevant connection. "As legislation that mood must be respected, even though it can serve only as a standard for judgment and not as a body of rigid rules assuring sameness of application."209 It cannot fairly be assumed that conscientious administrators will remain indifferent to the mood that Congress expresses in limiting their discretion to exercise summary authority. ${ }^{210}$

204 Some agencies, such as the Interstate Commerce Commission and the Environmental Protection Agency, may take summary action either on their own initiative or that of a complainant. See generally Jaffe, The Individual Right to Initiate Administrative Process, 25 IowA L. Rev. 485 (1940).

205 Most of the federal statutes authorizing summary rate suspension do not contain standards to guide agency decisions to suspend. See, e.g., statutes cited note 15 supra.

$208 \S 4(c), 7$ U.S.C. $\S 135 \mathrm{~b}$ (c) (1970).

207108 CoNG. REc. 17,366 (1962) (remarks of Senator Eastland).

208 See Environmental Defense Fund, Inc. v. Ruckelshaus, 439 F.2d 584, 596-97 (D.C. Cir. 1971).

209 Universal Camera Corp. v. NLRB, 340 U.S. 474, 487 (1951).

210 If there is reason to doubt that agencies will comply with the statutory standards Congress enacts, procedures to give greater assurance of agency compliance may be adopted; 
2. Rules and Reasons. Two procedures commonly used to structure formal administrative processes are the promulgation of rules for the exercise of a particular discretionary power and the provision of a statement explaining the agency's reasons in each instance for its discretionary acts. The existence of a body of standards tends to encourage greater deliberation, self-consciousness, and consistency in the exercise of administrative discretion and thereby reduces the likelihood that an agency will act arbitrarily.211 By promulgating rules and providing statements of reasons, an administrative agency creates a body of standards against which its performance can be measured by Congress, the courts, and the public, and thereby tends to make the law more democratic. ${ }^{212}$

These arguments have found renewed expression during the last decade in scholarly criticism ${ }^{213}$ and judicial decisions ${ }^{214}$ urging administrative agencies to make greater use of rules and reasons. The immediate question, however, is whether the promulgation of rules and guidelines and the provision of statements of reasons-practices grow-

for example, requiring that the members of the agency personally approve the decision to act summarily, as the Securities and Exchange Commissioners presently do, Interview with Irving M. Pollack, Director of the Division of Enforcement, Securities and Exchange Commission, in Washington, D.C., Jan., 1971; requiring an agency to secure the prior certification of the Attorney General that the statutory standards have been met, as the Food and Drug Administration must do before instituting summary seizures, Food, Drug, and Cosmetic Act $\$ 307,21$ U.S.C. $\$ 337$ (1946), as amended, 21 U.S.C. $\S 337$ (1970); see Memorandum from Mary Jane Checchi, Staff Attorney, Administrative Conference of the United States, to James O. Freedman, June 29, 1971, at 7 (copy on file at The University of Chicago Law Review); or providing for judicial review of administrative decisions to take summary action, see text at notes 257-271 infra. Because the cost of each of these procedures-in terms of delay, the possibility of prejudgment, the consumption of agency resources-will vary for each type of summary action, selection must be made on a function-by-function basis.

211 See H. Friendly, The Federal Administrative Agencies (1962); Redford, The Protection of the Public Interest with Special Reference to Administrative Regulation, 48 AM. PoL. Scr. REv. 1103 (1954). But see Wade, Anglo-American Administrative Law: Some Reflections, 81 L.Q. REv. 357 (1965).

212 Slawson, Standard Form Contracts and Democratic Control of Lawmaking Power, 84 Harv. L. Rev. 529, 535 (1971); see T. Lowi, The End of Liberalism (1969).

213 See, e.g., K. DAvis, supra note 203; H. FrIENDLY, supra note 211; AdMINISTRATIVe CoNference of the United States, Recommendation No. 25, ARticulation of Agency Policies (adopted May 7, 1971); Wright, Book Review, Beyond Discretionary Justice, 81 Yale L.J. 575 (1972). See also Shapiro, The Choice of Rulemaking or Adjudication in the Development of Administrative Policy, 78 Harv. L. REv. 921 (1965).

214 See, e.g., Kennecott Copper Corp. v. EPA, 462 F.2d 846 (D.C. Cir. 1972); United States v. Bryant, 439 F.2d 642, 652 \& $n .22$ (D.C. Cir. 1971); Holmes v. New York City Housing Authority, 398 F.2d 262 (2d Cir. 1968); Hornsby v. Allen, 326 F.2d 605 (5th Cir. 1964). For opinions indicating that reversal of administrative decisions might not have been necessary had published agency rules governed the situation under review, see Aquavella v. Richardson, 437 F.2d 397 (2d Cir. 1971); Gonzalez v. Freeman, 334 F.2d 570 (D.C. Cir. 1964). 
ing out of formal administrative processes-can be effective in structuring an agency's exercise of its discretion to invoke summary authority.

Section 3(a) of the Administrative Procedure Act requires agencies to "publish in the Federal Register for the guidance of the public(D) ... statements of general policy or interpretations of general applicability formulated and adopted by the agency."215 Despite this requirement, the policies that administrative agencies have developed for exercising their discretion to take summary action have not generally been published as rules or regulations or in any other form. In many instances, these policies appear only in internal memoranda prepared for the guidance of the agency's staff. The fact that these memoranda are unpublished increases the possibility of unequal treatment; knowledge of their substance is likely to be limited to "an elite clique of agency specialists," 216 many of them former members of the agency's legal staff, ${ }^{217}$ who alone can assert them on behalf of their clients. It also prevents any effective inquiry into whether the agency's enforcement policies are unequally applied in practice, particularly when a degree of autonomy has been granted to the agency's regional offices.

The explanation most often given by agency officials for not publishing rules for the exercise of summary authority is the difficulty of framing them. Most decisions to take summary action, it is said, are based on a highly developed expertise that gives the agency confidence in the refined quality of what are, essentially, educated guesses and hunches. To articulate criteria for taking summary action-the type of harm, the magnitude of the violation, the seriousness of the threat to the public interest, the substantiality of the agency's evidence, the availability of alternate relief, and the special characteristics of the individual involved, including his prior record of violations, his degree of culpability, and his vulnerability to successful action-would be, in the view of many administrators, to do no more than announce obvious generalities ${ }^{218}$ that would neither standardize an agency's decisionmaking processes nor provide the public with reliable information on how future cases, each of them turning on individual facts, are likely to be decided.219

2155 U.S.C. § 552(a) (1970).

216 Lockhart, supra note 203, at 176.

217 See Abrams, Internal Policy: Guiding the Exercise of Prosecutorial Discretion, 19 U.C.L.A.L. REv. 1, 27 (1971).

218 See Auerbach, Pluralism and the Administrative Process, 400 Annals 1, 6 \& n.20 (1972).

219 See Reiss, Book Review, 68 Mrcr. L. REv. 789, 792 (1970); Reiss, Research on Administrative Discretion and Justice, 23 J. LEGAL ED. 69, 73 (1970) (footnote omitted): “The literature on decision-making strongly suggests that an increase in alternatives reduces the 
Although this explanation has some validity, it is not wholly persuasive. Some administrative agencies have managed to formulate and publish rules defining the circumstances in which they take summary action. The Federal Home Loan Bank Board has, for example, promulgated rules governing the appointment of conservators. ${ }^{220}$ In addition, many agencies have published rules governing the circumstances in which they initiate adjudicatory proceedings, even though the criteria are as numerous and the facts as individually diverse as those involved when summary action is contemplated. Even when an administrative agency is reluctant to formalize its criteria for summary action in published rules, a useful purpose could still be served by making these criteria available in other forms, such as summaries of prior practices, illustrations of real or hypothetical situations at the extremes of enforcement and nonenforcement, digests of prior decisions to take summary action, and advisory interpretations. In considering whether to require a particular agency to promulgate rules governing its discretion in this area, Congress might wisely permit the agency some freedom to explore the utility of these other forms and methods.

A practical method by which an administrative agency can lay a foundation for the eventual promulgation of rules or guidelines is to provide a statement of reasons whenever it takes summary action. This would permit an agency gradually to develop generalized criteria out of particular fact situations and to refine them as experience recommends. Once an agency promulgates rules, it will be possible to discern any discrepancy between the agency's stated criteria for acting and the reasons given for acting in a particular case.

In authorizing administrative agencies to act summarily, Congress has only occasionally required that the agency provide a statement of reasons whenever it does so. ${ }^{221}$ The Interstate Commerce Act and the

capacity to discriminate among them. This seems to be true for all forms of cognitive discrimination.... Injustice may arise as much from many rules as it does from a relative lack of them."

22012 C.F.R. \& 547.1 (1972). The Administrative Conference has recommended that the Securities and Exchange Commission promulgate rules to govern a process as informal as the issuance of no-action letters. ADMinistrative CONFERENGE of THE UNITEd STATES, Recommendation No. 19, SEC No-Action LetTers Under Section 4 of the Securities Act of 1933, 1 ACUS 437 (1970). See also Administrattve Conference of the United States, Recommendation No. 34, Procedures of the United States Board of Parole (adopted June 9, 1972). For suggested statutory language that would have a similar effect on many areas of informal agency action, see Davis, Discretionary Justice, 23 J. LEGAL ED. 56, 60 n.4 (1970).

221 There is no constitutional requirement that administrative agencies state reasons for their decisions. Compare Panama Refining Co. v. Ryan, 293 U.S. 388, 432 (1935) (suggesting that due process so requires) with 2 ADMInISTRATIVE LAW TREATISE, supra note $37, \S 16.01$, at $436, \S 16.04$, at 442 and W. GELLhORN \& C. BYsE, supra note 46, at $979 \mathrm{n} .2$ (concluding 
various rate suspension statutes modeled after $\mathrm{it}^{222}$ are notable examples of statutes requiring explanations for each use of summary administrative authority. In most instances the requirement that administrative agencies state the reasons for their decisions has been of judicial origin, based both on the desirability of refining the exercise of administrative discretion and on the necessity of facilitating judicial review. ${ }^{223}$

The substantial number of judicial decisions requiring administrative agencies to state the reasons for their decisions are, however, limited almost entirely to formal agency proceedings. Although the purposes underlying the requirement of reasons-improvement of the exercise of discretion and prevention of arbitrary administrative action -are probably more in need of vindication when an agency acts informally than when it uses the formal hearing process, courts have only recently begun to require administrative agencies to provide a statement of reasons when they act informally.224

In Environmental Defense Fund, Inc. v. Ruckelshaus, ${ }^{225}$ the court remanded the case to the Administrator of the Environmental Protection Agency because it found that he had "not yet provided an adequate explanation for his decision to deny interim relief"226 to environmentalist groups seeking the summary suspension of the federal registration of DDT. The court explicitly instructed the Administrator to identify the factors he considered in reaching his decision and to relate them to the evidence before him. ${ }^{22 \tau}$ In Environmental Defense Fund, Inc. $v$. $E P A,{ }^{228}$ the same court remanded a similar case to the Administrator

that the doctrine died in infancy). The Administrative Procedure Act's requirement that "[a]ll decisions, including initial, recommended, and tentative decisions . . . include a statement of-(A) findings and conclusions, and the reasons or basis therefor," does not apply to summary action; it is limited to instances in which there has been a hearing required by statute. 5 U.S.G. § 557(a), (c)(3) (1970); see City of San Antonio v. CAB, 374 F.2d 326, 331 (D.C. Cir. 1967); Transcontinental Bus Sys., Inc. v. CAB, 383 F.2d 466 (5th Cir. 1967), cert. denied, 390 U.S. 920 (1968).

222 See statutes cited note 15 supra. See also Food, Drug, and Cosmetic Act § 505(e), 21 U.S.C. \& 355(e) (1970); Military Selective Service Act \& 22; 50 U.S.C.A. App. § 471a(4) (1971). 223 See, e.g., Burlington Truck Lines, Inc. v. United States, 371 U.S. 156 (1962); SEC v. Chenery Corp., 318 U.S. 80 (1943). See also Citizens to Preserve Overton Park, Inc. v. Volpe, 401 U.S. 402 (1971).

224 In addition to the two cases discussed in the text, see Medical Comm. for Human Rights v. SEC, 432 F.2d 659 (D.C. Cir. 1970), vacated as moot, 404 U.S. 403 (1972); Environmental Defense Fund, Inc. v. Hardin, 428 F.2d 1093 (D.C. Cir. 1970); United States v. Broyles, 423 F.2d 1299 (4th Cir. 1970).

225439 F.2d 584 (D.C. Cir. 1971); see DeVito v. Shultz, 300 F. Supp. 381 (D.D.C. 1969). 226439 F.2d at 596.

227 Id. The court held that findings of fact and statements of reasons would "diminish the importance of judicial review by enhancing the integrity of the administrative process ...." Id. at 598; cf. O'Neil, supra note 39 , at 188 (statements of reasons for summary action likely to increase predictability and consistency in administration).

228465 F.2d 528 (D.C. Cir. 1972). 
because of his failure to provide an adequate statement of reasons. The court regarded the interests at stake in the case as "too important to permit the decision to be sustained on the basis of speculative inference as to what the Administrator's findings and conclusions might have been" 229 regarding a central issue in the case.

The possibility that the courts will extend the two Environmental Defense Fund decisions by requiring other administrative agencies to provide a statement of reasons when they take summary action does not relieve Congress or the individual administrative agencies of their respective obligations to address the question of when a statement of reasons should accompany particular exercises of summary power. The general usefulness of statements of reasons is so plain that they probably should be required in most instances of summary action, as they already are in formal agency adjudication. In some circumstances, of course, the pressures of time will not permit an agency to prepare a statement of reasons before taking summary action. ${ }^{230}$ When preparation of a statement is impractical at the time summary action is taken, the agency should still be required to provide the statement within a specified time subsequent to the action. ${ }^{231}$

Once the decision has been made to require an administrative agency to provide a statement of reasons when it acts summarily, it is important that the statement be sufficiently elaborated to permit the respondent to know the actual basis for the agency's decision and to plan his subsequent strategy realistically. Statements of reasons that merely recite statutory phrases ritualistically do not serve this function. When the Interstate Commerce Commission suspends a proposed rate schedule, it gives one of six standard reasons-for example, that the proposed schedule is "unjust and unreasonable in violation of the Interstate Commerce Act"-each of which merely paraphrases a broad statutory requirement. ${ }^{232}$ If the agency issued a statement giving some

229 Id. at 539.

280 In both Environmental Defense Fund cases the court required a statement of reasons for administrative decisions not to take summary action-decisions "not ordinarily . . . made in a matter of moments, or even hours or days." Id. at 539.

231 Statements of reasons should not be required, of course, where the volume of the agency's business would prevent it from preparing meaningful statements. The Interstate Commerce Commission, for example, would have great practical difficulty preparing a statement of reasons each time it permits one of the hundreds of thousands of proposed tariffs filed with it annually to take effect without suspension. Situations of this kind are appropriate exceptions from a blanket requirement that reasons be given for each decision to take, or not to take, summary action.

232 See Letter from George M. Stafford, Chairman, Interstate Commerce Commission to Roger C. Cramton, Chairman, Administrative Conference of the United States, Feb. 28, 1972, at 3 (copy on file at The University of Chicago Law Review). 
sense of its reasoning rather than merely its conclusion, then, as Professor Spritzer has written, "the proponent obviously would be in a much better position to respond: to abandon the proposal, or particular features of it; to withdraw the pending proposal and submit an appropriately modified version that might pass muster; or to go forward with an awareness of the issue or issues that would have to be litigated to the agency's satisfaction."233

By promulgating rules describing generally the criteria that guide its discretion in taking summary action and by providing an informative statement of reasons whenever it does act summarily, an administrative agency can make one of its most significant informal processes more visible. These reforms would be an important step toward strengthening the fairness of the process by which summary action is taken. Sunlight, as Justice Brandeis said, is the best of disinfectants. ${ }^{234}$

3. Prior Informal Discussions. A fundamental problem of summary action is the risk of error created when an administrative agency must act quickly, often on incomplete information, always on information untested by the adversary process of a hearing. This risk is tolerated because formal adjudicatory hearings, with their careful, deliberative consideration of the evidence, are inconsistent with effective governmental action in emergency situations. Informal procedures preceding the final decision to take summary action can, however, be effective in reducing the risk of error in what may be a decision with drastic consequences for the individual involved.

Requiring an administrative agency to inform an individual that it is contemplating summary action against him, to describe the general nature of its information and the tenor of its reasoning, and to permit him a brief opportunity to discuss the matter with the agency's staff and advance arguments why summary action should not be taken could be most helpful in reducing the risk of error. Warner Gardner, in his proposed "Informal Procedure Act of 1980," would provide that before an administrative agency initiates action that "might impose a penalty or detriment or deny a benefit"-a formulation broad enough to embrace summary action-it must, "to the extent practicable," advise the persons affected that such action is under consideration and "give them a reasonable opportunity to supply relevant facts and the reasons why such agency action should or should not be taken."235

233 Spritzer, supra note 131, at 61-62.

234 L. BrAndeIs, OTher People's MONey 92 (1914).

235 Gardner, supra note 203, at 163-64. See also Lockhart, supra note 203, at 194-97. The only similar provision currently in force, section 9(b) of the Administrative Procedure Act, 5 U.S.C. $\$ 558(c)(1970)$, is limited to prohibiting an agency from suspending a license 
Despite the absence of any explicit requirement of law, several administrative agencies now follow a general practice of engaging in informal discussions before taking summary action. The Suspension Board of the Interstate Commerce Commission, for example, often holds informal discussions, usually by telephone, with carriers or their representatives before deciding whether to suspend proposed tariffs summarily. ${ }^{236}$ The Food and Drug Administration, prior to instituting summary seizures, often enters into informal recall discussions ${ }^{237}$ initiated by firms that have either been informed in writing, as the statute requires, ${ }^{238}$ that an inspector has found violations of law on their premises or have seen the results, routinely referred to them, of sample analyses indicating violations of law. The Securities and Exchange Commission, before summarily suspending trading in a security, often discusses the matter informally with the company involved and its counsel, and seeks their cooperation in working out a less drastic method for protecting the public..239

These practices indicate that it is feasible in some contexts for administrative agencies to inform an individual that summary action is contemplated and permit him an opportunity for informal discussion before it is taken. The sound identification of these contexts is crucial; if prior informal notice is required or given in inappropriate contextsfor example, to a taxpayer suspected of engaging in fraud-the social consequences may be more severe than the risk of error that notice is designed to reduce. ${ }^{240}$ Whether prior notice is appropriate in a particular context is a function of the degree to which the decision to act summarily depends on an understanding of the facts that may be mistaken; the degree to which the time required to conduct an informal

unless the licensee has been given written notice before institution of proceedings and an "opportunity to demonstrate or achieve compliance," except when the "public health, interest, or safety requires otherwise," the classic circumstances in which summary action is justified. There is no similar constitutional requirement. See Ewing v. Mytinger \& Casselberry, Inc., 339 U.S. 594 (1950); SEC v. Alan F. Hughes, Inc., 461 F.2d 974 (2d Cir. 1972). But the decision in Blackwell College of Business v. Attorney Gen., 454 F.2d 928 (D.G. Cir. 1971), may move in that direction: "[The] wide latitude and discretion inevitably given to executive officials and adminstrative agencies in regard to enforcement policy puts upon them a corresponding obligation to institute and abide by procedures that give affected persons a meaningful opportunity, before adverse decisions are crystallized, to make an appeal to their discretion." Id. at 932.

236 See P. Woll, supra note 51, at 82-83 (1963); Spritzer, supra note 131, at 55-56.

237 Memorandum from Mary Jane Checchi, supra note 210, at 2.

238 Food, Drug, and Cosmetic Act § 704(b), 21 U.S.C. § 374(b) (1970).

239 See Nelson, Discussions with Agency Staff Representatives Before Adjudicatory Hearings Commence, 12 AD. L. BuLL. 41 (1959); Woll, The Development of Shortened Procedure in American Administrative Law, 45 CORNELL L.Q. 56, 70-71 (1959).

$240 \mathrm{Cf}$. Otis \& Co. v. SEC, 106 F.2d 579, 583-84 (6th Cir. 1939). 
prior discussion would reduce the effectiveness of any summary action eventually taken; and the volume of business and amount of staff time that a practice of prior notice and informal discussion would involve. ${ }^{241}$ Quite plainly, these considerations cannot be applied at large, but they can be applied on a particularized basis, agency-by-agency and functionby-function.

Similarly, the specific shape that informal discussions should takehow complete a description of its evidence and outline of its reasons the agency should provide, whether the individual may submit documentary evidence, affidavits, or a written statement in the nature of a brief, for how long a period the discussions should be permitted-will necessarily vary with the particular agency and the particular summary power involved.2*2 Resolution of these questions may have to reflect the varying degree to which informal discussions between staff and the individual against whom summary action is contemplated may become a process of detailed negotiation into which the members of the agency, who have the ultimate power of decision, will be improperly drawn. ${ }^{243}$ Again, the seriousness of that danger and its implications for a practice of informal discussions prior to taking summary action must be individually assessed by and for each agency exercising summary authority. ${ }^{244}$

The evident desirability of particularized adaptations to a norm of informal discussion prior to taking summary action indicates caution in enacting legislation. For many agencies, statutory prescription would be premature, particularly if they have not employed informal procedures of prior discussion in the past. These agencies should first-or should first be required to-devise and adopt informal discussion procedures tailored to reducing the risk of error created by the specific type of summary authority they exercise. Experience with the varying procedures that doubtless can be devised may then supply a basis for informed legislative action.

4. Expedited Hearings. The prolonged delay that sometimes occurs between the time an agency takes summary action and the time an adjudicated hearing is held is one of the most egregious consequences of the failure to structure the use of summary authority. In Gonzalez $v$.

241 See Lockhart, supra note 203, at 195.

242 For useful suggestions in particular contexts, see, e.g., Yakus v. United States, 32l U.S. 414, 428 (1944); National Airlines, Inc. v. CAB, 306 F.2d 753 (D.C. Cir. 1962); Comm'N ON ORGANIZATION OF THE EXECUTTVE BRANCH OF THE GOVERNMENT, supra note 150, at 146-48; Freeman, supra note 148, at 894-95.

243 Compare Moss v. CAB, 430 F.2d 891 (D.C. Cir. 1970) with Public Util. Comm'n v. United States, 356 F.2d 236 (9th Cir.), cert. denied, 385 U.S. 816 (1966).

244 See Independent Broker-Dealers' Trade Ass'n v. SEC, 442 F.2d 132, 144 (D.C. Cir.), cert. denied, 404 U.S. 828 (1971). 
Freeman, ${ }^{245}$ for example, the Secretary of Agriculture's summary order debarring a businessman from eligibility for certain government contracts on account of alleged misuse of official inspection certificates remained in effect for twenty-eight months without a hearing being held. In Aquavella v. Richardson, ${ }^{246}$ the Secretary of Health, Education, and Welfare's summary order suspending medicare payments to a nursing home remained in effect for eighteen months without a hearing being held. In Beacon Federal Savings \& Loan Association v. FHLBB, 247 the Board's summary order appointing a Supervisory Representative in Charge of a banking institution remained in effect for five months before a hearing was held and fourteen months before the Board adopted the hearing examiner's recommended decision.

The justification for summary action, as an exception to the general rule that an administrative agency may act against an individual only after granting him a hearing, lies in the necessity for the government to act immediately if public policy is to be enforced at all. Having invoked the exception to achieve its immediate objectives, an administrative agency has an obligation in fairness to hold an adjudicatory hearing promptly so that the adverse impact of its summary order on the individual will be confined to the shortest possible period. ${ }^{248}$ Congress should take steps to insure that this obligation is met.

One step Congress could take would be to require that all federal agencies taking summary action expedite the subsequent adjudicatory hearing in every way consistent with sound administrative resolution

245334 F.2d 570 (D.G. Cir. 1964). See also Horne Bros., Inc. v. Laird, 463 F.2d 1268 (D.C. Cir. 1972).

246437 F.2d 397 (2d Cir. 1971).

247162 F. Supp. 350 (E.D. Wis. 1958), appeal dismissed, 266 F.2d 246 (7th Gir.), cert. denied, 361 U.S. 823 (1959).

248 See Horne Bros. Inc. v. Laird, 463 F.2d 1268 (D.C. Cir. 1972) (hearings ordered within a specified number of days); Mack v. Florida State Bd. of Dentistry, 430 F.2d 862, 864 (5th Cir. 1970), cert. denied, 401 U.S. 954, 960 (1971); Stricklin v. Regents of Univ. of Wis., 297 F. Supp. 416, 420 (W.D. Wis. 1969), appeal dismissed, 420 F.2d 1257 (7th Cir. 1970) (hearing ordered "at the earliest practical time"). One court has suggested that if the delay is "too long to be justifiable," the action "must be regarded as unlawful during the delay." $\mathrm{La}$ Bonte v. Berlin, 85 N.H. 89, 95, 154 A. 89,93 (1931). The unfairness caused by prolonged delay may ultimately assume constitutional dimensions if, as Judge Wyzanski recently said, the due process guarantee of a prior administrative hearing "may be validly limited [by summary action] only for the briefest of periods." United States v. Harper, 335 F. Supp. 904, 906-07 (D. Mass. 1971), vacated as moot, 406 U.S. 940 (1972); cf. Fuentes v. Shevin, 407 U.S. 67, 86 (1972): "The Fourteenth Amendment draws no bright lines around threeday, 10-day or 50-day deprivations of property. Any significant taking of property by the State is within the purview of the Due Process Clause. While the length and consequent severity of a deprivation may be another factor to weigh in determining the appropriate form of hearing, it is not decisive of the basic right to prior hearing of some kind." 
of the issues presented. Some federal statutes presently contain provisions mandating expedited administrative hearings after summary action has been taken.49 Institutional considerations, however, may stand in the path of their effectiveness. Once an administrative agency has taken summary action, it is no longer under immediate pressure to resolve the matter in dispute. Summary action places the pressure for an expedited adjudicatory hearing on the individual; he must persuade the agency to grant him a prompt hearing, while the agency is probably content with the status quo. A statutory requirement of expedition may not be sufficient to alter this balance of pressures. Moreover, even when an agency is prepared to grant an expedited hearing, whether or not it is required by statute to do so, the individual will often be unable to take advantage of it because of the disabling injury that the agency's exercise of summary authority will have inflicted ${ }^{250}$ and the limitations that expedition imposes on the development of complex issues.

As an alternative to requiring an expedited hearing following summary action, Congress could provide that summary orders would be effective for only limited periods of time. Such provisions must obviously be tailored on an agency-by-agency, function-by-function basis. Congress has already demonstrated the capacity to make individualized judgments of this sort. Summary orders of the Securities and Exchange Commission suspending trading in a security, for example, are limited by the Securities Exchange Act to ten days' duration. ${ }^{251}$ Summary orders of the Interstate Commerce Commission suspending proposed tariffs are effective for seven months; if the Commission has not ruled upon the validity of the proposed tariffs by the expiration of that period, the carrier is free to put them into effect. ${ }^{252}$

By giving an agency an incentive to move forward to completion of an adjudicatory hearing, statutory provisions limiting the effective periods of summary orders may be more effective than statutory requirements of expedition in reducing the incidence of prolonged delays. Limitation provisions would distribute the pressures to proceed

240 See, e.g., Federal Insecticide, Fungicide, and Rodenticide Act $\S 4$ (c), 7 U.S.C. § $135 \mathrm{~b}$ (c) (1970); Food, Drug, and Cosmetic Act § 404, 21 U.S.C. § 344 (1970).

250 See text at notes 162-65 supra:

$251 \S 19(a)(4)$, I5 U.S.C. $\S 78 \mathrm{~s}(a)(4)(1970) ; \S 15(c)(5), 15$ U.S.C. $\S 78 o(c)(5)(1970)$. But the Commission often "tacks" one ten-day suspension period onto another if it determines that circumstances require continuation of the suspension period. See 5 L. Loss, supra note 172, at 2814-15. The question whether such a procedure has been endorsed by Congress, or rather is an evasion of its limited duration requirement, is discussed id. at 2825.

252 Interstate Commerce Act $\$ 15(7)$, 49 U.S.C. $\S 15(7)$ (1970); see Arrow Transp. Co. v. Southern Ry., 372 U.S. 658 (1963). 
to an adjudicatory hearing more equally between the agency and the individual, creating a common interest in expedition that may not exist if the statute simply directs an expedited hearing. ${ }^{253}$

The effectiveness of limitation provisions in reducing prolonged delays may sometimes be secured, however, at the expense of other values. When an administrative agency would be unable to hold an adjudicatory hearing promptly because it lacks the staff and resources to complete its investigation and prepare its case adequately in the limited time available, a difficult choice confronts it. It may choose not to act summarily, even though it is convinced that the public interest so requires. Provisions limiting the effective periods of summary orders may thus compel an agency to make more selective use of a remedy already restricted to emergency situations. ${ }^{254} \mathrm{Or}$, in order to protect the public interest for the limited period that its order can have effect, an agency may choose to act summarily anyway, inflicting injury on an individual who it knows will not receive an opportunity to contest the merits before the order expires. Even if not prohibited by statutory provisions limiting the effective periods of summary orders, the latter course consists uneasily with the constitutional theory allowing summary action on condition that the individual have an adequate opportunity for a subsequent adjudicatory hearing. It also permits the individual, when the statutory period of limitation expires, to resume the very conduct that threatened the public interest sufficiently to require summary action in the first place.

These considerations suggest that Congress should impose statutory limitations on the effective periods of summary orders-rather than limiting itself to requiring expedited hearings-only after a particularized examination of the agency and function involved. Congress need not, of course, prescribe the specific period of limitation in order to adopt the principle that particular summary orders should be of limited duration. But it should at least require the agencies to provide by rule for reasonable but specific periods of limitation, just as some agencies have promulgated rules requiring hearing examiners, for example, to

253 Compare 7 J. Moore, Federal Practice If 65.07 (2d ed. 1972) (discussing Fed. R. Crv. P. 65 (b)).

254 Congress might mitigate the impact that limiting the effective period of summary orders might have on enforcement policy and practice by providing that an agency need only commence an adjudicatory hearing to toll the limitation. Assuming the agency did not prolong the hearing unnecessarily, the summary order would then remain in effect until the hearing was completed. Such a provision would create an incentive for the agency to move expeditiously to a hearing (although inadequacies of staff and resources could still prevent it from acting) and yet permit a more deliberative hearing than could be conducted within the limitation period. 
file their initial decisions within a specified number of days after the record is completed.255 Engaging the responsibility of agencies on matters of this kind is almost always a wise and practical course.

\section{Judicial Review of Summary Action}

Congress has only rarely exercised its power $^{256}$ to permit ${ }^{257}$ or preclude $^{258}$ judicial review of summary administrative action. The absence from most statutes of a clear expression of Congress's intention has compelled the courts to decide the question of the availability of judicial review for themselves, to strike a careful balance between the need for adequate protection of individual interests and the need for effective and responsible administrative action. In so doing, they have sought guidance from various sources and considerations, including the common law presumption of the reviewability of administrative action;269 inferences, drawn from the statutory scheme, of a legislative intention to preclude judicial review; ${ }^{200}$ the relevant provisions of the Administrative Procedure Act; ${ }^{201}$ the appropriateness of the issues for judicial resolution; ${ }^{262}$ the seriousness of the impact of the agency's action on the individual; ${ }^{263}$ and the distuption and interference that judicial review would create in the administrative process. ${ }^{264}$

Because Congress does have the power to legislate in this area, however, the fact that courts have heretofore played a prominent role in determining the availability of judicial review does not conclude the matter. Congress has an independent obligation to consider the role that judicial review should play in insuring that summary authority is fairly exercised.

255 See, e.g., 16 G.F.R. § 3.51(a) (1972) (Federal Trade Commission). See also Gellhorn \& Robinson, supra note 171 , at 621 n.48.

256 See, e.g., Lockerty v. Phillips, 319 U.S. 182, 187 (1943); Cary v. Curtis, 44 U.S. (3 How.) 236, 245 (1848).

257 See, e.g., Federal Meat Inspection Act \$§ 402-03, 21 U.S.C. \$§ 672-73 (1970).

258 National Housing Act $\S 407(\mathrm{k})(2), 12$ U.S.C. $\S 1730(\mathrm{k})(2)$ (1970); Hykel v. Federal Sav. \& Loan Ins. Corp., 317 F. Supp. 332 (E.D. Pa. 1970).

259 See 4 ADMinistrative LAW TREATISE, supra note 37, § 28.04; L. JAFFE, suppra note 66, at $336-53$.

260 See, e.g., Arrow Transp. Co. v. Southern Ry., 372 U.S. 658 (1963); Port of N.Y. Authority v. United States, 45I F.2d 783 (2d Cir. 1971); cf. Students Challenging Regulatory Agency Procedures v. United States, 346 F. Supp. 189 (D.D.C.), prob. juris. noted, 41 U.S.L.W. 3346 (Dec. 18, 1972).

2615 U.S.C. $\$ \S 702-06(1970)$.

202 See, e.g., Hahn v. Gottlieb, 430 F.2d 1243 (1st Cir. 1970).

263 See Abbott Laboratories v. Gardner, 387 U.S. 136 (1967); Aquavella v. Richardson, 437 F.2d 397 (2d Cir. 1971).

264 See Nor-Am Agricultural Prods., Inc. v. Hardin, 435 F.2d 1151, rev'g on rehearing en banc 435 F.2d 1133 (7th Cir. 1970), petition for cert. dismissed, 402 U.S. 935 (1971);

Greater Del. Valley Fed. Sav. \& Loan Ass'n v. FHLBB, 262 F.2d 371 (3d Cir. 1958). 
The specific contexts in which summary powers are exercised are so various that a single, undifferentiated response-for example, enactment of a statute of general application or amendment of the Administrative Procedure Act to permit or preclude judicial review of all summary action-would be impractical. Permitting judicial review of all summary action might hardly interfere with some administrative processes but seriously disrupt others; precluding any judicial review might expose individuals to injuries harsh and senseless in some contexts but quite justifiable in others. Legislative decisions concerning judicial review of summary action can be made wisely only on an agency-by-agency, function-by-function basis. ${ }^{265}$

In making these decisions, Congress should take into account not only the factors that courts have considered relevant in determining the availability of judicial review but also other considerations that, although not often expressed in judicial opinions, have probably influenced the results courts have reached. First among these is the confidence that Congress itself has in an agency's competence and sensitivity in exercising summary authority. ${ }^{266}$ If Congress is uncertain about a particular agency's capacity to exercise summary authority fairly, it should consider whether the availability of judicial review would motivate the agency to a higher standard of performance. Second, the probable effectiveness of judicial review in preventing unnecessary injury to an individual against whom summary action has been taken must be weighed realistically in evaluating the advisability of providing for review of particular types of summary action. Judicial review may not be effective, for example, where summary action may wrongfully inflict irremediable damage, ${ }^{267}$ or where the court pays great deference to administrative expertise, as it is likely to do in scientific and technical areas. ${ }^{268}$ If judicial review would not be effective in protecting the individual, it may as well be precluded and judicial resources conserved.

There is much to be said for leaving the entire question of judicial review of summary action to the courts, particularly if agencies adopt

205 Cf. Freedman, Review Boards in the Administrative Process, 117 U. PA. L. REv. 546, $571-75$ (1969).

266 Cf. 1 F. Cooper, State Administrative Law 141 (1965): "A court that views with doubts and misgivings the functioning of a given agency is naturally inclined to repress that agency's freedom of discretionary action."

267 See SEC v. Jones, 298 U.S. 1 (1936); J. LANDIs, supra note 13, at 108-09; Conference on the Codification of the Federal Securities Laws, 22 Bus, LAw. 793, 902 (1967) (remarks of Friendly, J.).

268 See, e.g., Kletschka v. Driver, 411 F.2d 436 (2d Cir. 1969); Spivak, Regulation of Medical Devices, 400 Annals 82, 88 (1972); Note, The Role of the Courts in Technology Assessment, 55 CoRnell L. REv. 861, 873 \& n.77 (1970); cf. Hand, Historical and Practical Considerations Regarding Expert Testimony, 15 HARV. L. REV. 40 (1901). 
effective administrative procedures for protecting the individual. Recent decisions of the Supreme Court have focused on the role of summary action and the timing of judicial review in our legal system, ${ }^{269}$ stimulating reconsideration of problems the relevant dimensions of which may not yet have fully been perceived. Codification of existing principles of judicial review of summary action might prematurely restrict the courts' resourcefulness in fashioning wise solutions to these problems. In addition, the courts are probably better situated institutionally than Congress to appreciate the factors relevant to a decision to review specific forms of summary action and to see those factors in the larger context of social values that a system of judicial review is designed to serve. 270

Judicial review is not adequate by itself, however, to prevent abuses in the exercise of summary authority. It can stop agencies from carrying out unwise decisions to act summarily and can protect individuals from additional injury, but it cannot insure that agency decisions to act summarily are wisely made. Conscientious administrators who appreciate the responsibilities of their power are likely to serve that ideal better than judges exercising the function of judicial review. "Constitute government how you please," wrote Edmund Burke, "infinitely the greater part of it must depend upon ... the prudence and uprightness of ministers of state."271

\section{Preliminary Injunctions as an Alternative to Summary AGtion}

A significant alternative to granting an administrative agency authority to act summarily is to empower it to seek a preliminary injunction from a United States district court pending completion of the administrative proceedings. ${ }^{272} \mathrm{~A}$ preliminary injunction serves the same basic purpose as a summary administrative order: it permits an agency to act at what may be the only point in time at which effective action can

269 See, e.g., Goldberg v. Kelly, 397 U.S. 254 (1970); Abbott Laboratories v. Gardner, 387 U.S. 136 (1967).

270 See L. JAFFE, supra note 66, at 327; cf. Parker, The Execution of Administrative Acts, 24 U. CHI. L. REv. 292 (1957); Sofaer, Judicial Control of Informal Discretionary Adjudication and Enforcement, 72 Colum. L. REv. 1293 (1972).

271 I E. BuRkE, WORks 379 (rev. ed. 1865) (orig. ed. 1770).

272 See Comment, The Statutory Injunction as an Enforcement Weapon of Federal Agencies, 57 Yale L.J. 1023 (1948). See also O. Fiss, InJunctions 168-86 (1972). As to whether an administrative agency may obtain a preliminary injunction from a federal court without express statutory authorization, compare, e.g., NLRB v. Nash-Finch Co., 404 U.S. 138 (1971) and FTG v. Dean Foods Co., 384 U.S. 597 (1966) with EEOC v. Woolco Dep't Store, 321 F. Supp. 811 (E.D. La. 1971); see Note, Interim Injunctive Relief Pending Administrative Determination, 49 CoLum. L. REv. 1124 (1949). 
be taken. Like a summary order, a preliminary injunction can prevent a possible violation of law from occurring until an administrative hearing on the merits can be held; and by preserving the status quo, it can preserve an agency's jurisdiction eventually to enter an order vindicating the public interest.

Congress has granted several agencies authority to seek preliminary injunctions pending completion of administrative proceedings in situations in which it has denied them authority to act summarily. ${ }^{273}$ The National Labor Relations Board, for example, has the authority under the Taft-Hartley Act to seek injunctive relief pending the disposition of administrative hearings in two circumstances: "upon issuance of a complaint . . . charging that any person has engaged in or is engaging in an unfair labor practice"; 274 and whenever there is "reasonable cause to believe" that a union is engaged in a boycott or an illegal strike.275 The Board has rarely used its discretionary authority to seek preliminary injunctions against unfair labor practices, ${ }^{276}$ but it has invoked the mandatory injunction section against coercive union activities on thousands of occasions. ${ }^{277}$ The Federal Trade Commission also has authority to seek preliminary injunctions-against dissemination of false advertising relating to foods, drugs, devices, and cosmetics, ${ }^{278}$ and against violations of a number of labeling laws ${ }^{279}$-pending completion of cease and desist order proceedings. The Commission has made sparing use of this authority. ${ }^{280}$

273 Some agencies have been granted authority to seek injunctive relief against persons believed to be violating the law as part of statutory schemes contemplating that a judicial hearing on permanent relief, rather than an administrative hearing, will follow. See, e.g., Securities Act of 1933 \& 20(b), 15 U.S.G. \& 77t(b) (1970); Federal Power Act § 314, 16 U.S.C. § 825m(a) (1970); Interstate Commerce Act § 222, 49 U.S.C. § 322(b) (1970); Equal Employment Opportunity Act of 1972, Pub. L. No. 92-261, §§ 4-5, amending 42 U.S.C. $\S \S 2000 \mathrm{e}-5(\mathrm{a})-(\mathrm{g})$, (j) (1970). The Food and Drug Administration, however, has been granted a choice of judicial or summary administrative remedies when certain violations of law occur. See Food, Drug, and Cosmetic Act $\S 302,21$ U.S.C. $\S 332(1970)$ (preliminary injunction); id. § 304, 21 U.S.C. $\S 334$ (1970) (libel); Drug Abuse Control Amendments of 1965 \& 8(a), 21 U.S.C. \& 372(e) (1970) (executive seizure).

274 National Labor Relations Act \$ 10(j), 29 U.S.C. § 160(j) (1970).

$275 I d$. $\S 10(l), 29$ U.S.C. $\S 160(l)(1970)$.

276 See 1970 NLRB ANn. Rep. 126; Advisory Panel on Labor-Management Relations Law, Organization and Procedure of the N.L.R.B., S. Doc. No. 81, 86th Cong., 2d Sess. 12 (1960); Bok, The Regulation of Campaign Tactics in Representation Elections under the National Labor Relations Act, 78 HARv. L. Rev. 38, 129 (1964); Note, NLRB Power to Award Damages in Unfair Labor Practice Cases, 84 HARv. L. Rev. 1670, 1671 n.12 (1971).

277 See 1970 NLRB ANN. REP. 130.

278 I5 U.S.C. \& 53 (1970).

279 Wool Products Labeling Act $\S 7,15$ U.S.C. $\S$ 68e (1970); Fur Products Labeling Act $\S 9,15$ U.S.C. $\S 69 \mathrm{~g}$ (1970); Textile Fiber Products Identification Act $\S 8,15$ U.S.C. $\S 70 f$ (1970); Flammable Fabrics Act § 6, 15 U.S.C. § 1195 (1970).

280 See Kintner, Federal Trade Commission Regulation of Food, Drug, and Cosmetic 
Given the similarity in basic purpose of preliminary injunctions and summary administrative orders, what considerations should Congress take into account in choosing between them? When Congress grants an administrative agency authority to seek a preliminary injunction rather than to act summarily, it indicates a preference for certain fundamental values that the federal judiciary is designed to preserve and declines to subordinate those values to the regulatory needs of the agency. A legislative choice of the preliminary injunction model conforms with the norm of our society that the coercive power of government should not be applied until an impartial judge has confirmed that the proposed action is lawful. By obliging an administrative agency with a specialized regulatory mission to justify its contemplated action to a generalist court of law, a preliminary injunction proceeding permits a range of legal and social values wider than mere regulatory necessity to inform the decision. And by formalizing a process of decision that would otherwise be informal-by placing it in a public forum and (except when a temporary restraining order may be issued ex parte) by granting notice to the individual who will be affected-a preliminary injunction proceeding may tend to reduce the risk of error ${ }^{281}$ and the possibility of excessive coercion. ${ }^{282}$ Finally, an individual against whom a preliminary injunction has been entered has a right to judicial review, a substantial

Advertising, 16 Bus. LAw. 81, 88 (1960). The Commission recently sought a temporary injunction for the first time in 10 years. See FTC v. Medi-Hair Int'I Corp., 3 TRADE REG. REP. I 19,478 (E.D. Cal., Feb. 11, 1971); cf. Weston, Deceptive Advertising and the Federal Trade Commission: Decline of Caveat Emptor, 24 FED. B.J. 548, 551 (1964).

281 It is sometimes suggested that a preliminary injunction is capable of greater definition, precision, and discrimination than a summary order and is therefore less likely to err by overbreadth. This suggestion is difficult to maintain as a general proposition, although it more obviously may be true of a permanent injunction issued after a full hearing. Because injunctions are enforceable by contempt proceedings, however, courts are likely to be more concerned than are agencies acting summarily with ensuring that the terms of their decrees are no "broader than . . . necessary to prevent evasion." Comment, supra note 272, at 1051.

282 The coercive impact of summary administrative orders and preliminary injunctions alike is often intensified as the period during which they remain in effect, not infrequently a year or more, lengthens. See FTC v. Dean Foods Co., 384 U.S. 597, 621-22, 634-35 (1966) (Fortas, J., dissenting); FTC v. National Health Aids, Inc., 108 F. Supp. 340, 346 (D. Md. 1952). Delay by an administrative agency after it has obtained a preliminary injunction "may make it seem that judicial restraint and administrative non-action are combining to enforce a judicial rather than an administrative settlement of the dispute, contrary to the manifest intention of Congress." Douds v. Wood, Wire, \& Metal Lathers Int'l Ass'n, 245 F.2d 223, 226 (3d Cir. 1957). Although an individual subject to a summary administrative order can petition a court to accelerate the proceeding, see Goldman, Administrative Delay and Judicial Relief, $66 \mathrm{MrcH}$. L. REv. 1423 (1968), courts may well be readier to control the duration of their own orders, vacating preliminary injunctions on grounds of administrative delay, than to set aside an agency's summary order because the agency has let too much time pass without a hearing. 
protection not always available when an administrative agency acts summarily.

There are practical considerations, however, that may temper the advantages Congress can achieve by authorizing an administrative agency to seek a preliminary injunction rather than to act summarily. It is surely true, although not capable of precise proof, that a symbolism attaches to the choices Congress makes in distributing power among governmental institutions. A decision to permit an administrative agency to take summary action in emergency situations-without requiring it to seek the approval of a court-is a demonstration of Congress's faith in the agency's maturity and judgment. By thus indicating its confidence in an agency, Congress enhances its stature and enables it to act with increased authority. Conversely, by denying an agency the authority to act summarily and requiring it instead to seek a preliminary injunction from a court, Congress may impair the agency's stature and encourage the regulated industry to deny the agency the respect necessary to promote its regulatory effectiveness.

In addition, whenever the effectiveness of a regulatory response turns on its promptness, a preliminary injunction may be less effective than a summary administrative order. The Federal Trade Commission, for example, generally requires at least a week to bring before a judge an application for a preliminary injunction against false advertising. Before the Commission can go to court, it must prepare an order to show cause, a petition for relief, affidavits by scientific experts, a memorandum of law, and a final order for the court to sign. ${ }^{283}$ When the application is made in a court outside Washington, the Commission must enlist the assistance of the local United States Attorney, who may want a day or two to examine the papers before signing them and may require some persuading if he is reluctant to proceed. ${ }^{284}$ By the time that the Commission has completed this preparatory work, an unlawful advertising campaign may have been successful in achieving its desired effect.

Even when an agency's application for a preliminary injunction receives a preferred place on a court calendar, the court may not be able to issue an injunction until several days after the time at which the

283 Interview with Harold D. Rhynedance, Jr., Assistant General Counsel, Federal Trade Commission, in Washington, D.C., Feb., 1971.

284 See Comment, supra note 272 , at $1035 \mathrm{n} .51$. The preparatory process may be even longer for an agency that must have the approval of the Attorney General before going to court. See Ewing v. Mytinger \& Casselberry, Inc., 339 U.S. 594, 599 (1950); FTC v. Guignon, 390 F.2d 323, 336 (8th Cir. 1968). 
agency could have issued a summary order. If substantial evidentiary support is required, the court may need a longer period to reach a decision.285 If the court denies the injunction, more time must pass while the agency takes an appeal; or if it grants the injunction, the respondent may appeal. In either event, the requirement that the agency obtain a preliminary injunction prevents it from responding with the promptness and certainty of success that the authority to act summarily would permit. It is indeed possible that the cumulative effect of these factors may sometimes discourage an agency from seeking a preliminary injunction when it would unhesitatingly issue a summary order if it had the authority to do so, an inhibiting effect that Congress must consider in deciding whether to authorize an agency to proceed by means of a preliminary injunction rather than a summary administrative order.

It should be noted that the process by which some administrative agencies decide to take summary action may itself be quite extended. The Food and Drug Administration, for example, sometimes requires several weeks to process a field representative's recommendation that summary seizures be instituted, particularly when the recommendation raises scientific questions requiring extensive laboratory analysis and legal and policy evaluation. ${ }^{286}$ When an administrative agency requires considerable time to take summary action after an unlawful condition comes to its attention, Congress should consider whether the preliminary injunction procedure is not the more appropriate method of regulation, since it is difficult to maintain that an "emergency" justifying summary action exists in such circumstances. ${ }^{287}$

While Congress can grant an administrative agency the authority to act summarily only when an "emergency" exists in the constitutional sense, there is no analogous constitutional limitation on Congress's power to authorize an administrative agency to seek a preliminary injunction. This consideration may make preliminary injunctions more attractive in some contexts. In Angle v. Sacks, ${ }^{288}$ for example, the court held that the Taft-Hartley Act authorized the National Labor Relations

285 See Note, "Corrective Advertising" Orders of the Federal Trade Commission, 85 HARv. L. REv. 477, 486-87 (1971).

280 Memorandum from Mary Jane Checchi, supra note 210, at 7-8.

287 Cf. Angle v. Sacks, 382 F.2d 655, 661 (10th Cir. 1967): “The more time that elapses between the time the incidents occur the less effective injunctive relief becomes, and it becomes increasingly difficult to show it to be a 'just and proper' remedy. 'This could, of course, reach a point where relief should be denied on that ground alone."

$288 \mathrm{Id}$. Although the court was interpreting the meaning of statutory language, its reasoning necessarily governs the constitutional question. 
Board to seek a preliminary injunction when it had "reasonable cause to believe that unfair labor practices had occurred." 289 The court rejected the argument that the Board's discretion to seek such relief should be limited to "rare emergency situations" that endanger the national welfare or have " 'heavy and meaningful repercussions' [for] a demonstrably prejudicial impact on the public." 290 Congress is thus free to authorize an administrative agency to seek a preliminary injunction when it would be prohibited constitutionally from authorizing it to act summarily.

In addition to being more widely available than summary action, preliminary injunctions authorized by statute are a more flexible remedy than preliminary injunctions resting on the general equity powers of courts. It is familiar teaching that a court will not grant a preliminary injunction without a clear showing that the petitioner has no adequate remedy at law; that he will probably succeed at an eventual trial on the merits; that he will suffer irreparable injury unless the preliminary injunction is granted; and that the injury he will sustain if relief is denied is greater than the injury others will suffer if it is granted. But Congress is not bound by the traditional criteria of equity courts in setting the conditions on which a court may grant a preliminary injunction authorized by statute. It may relax these standards if it determines that the acts prohibited by the statute are sufficiently serious to warrant issuance of a preliminary injunction on a less persuasive demonstration. ${ }^{201}$

The National Labor Relation Act, for example, authorizes the courts to grant the Board such equitable relief against unfair labor practices "as [the court] deems just and proper." 292 In construing this conclusory phrase, courts have held that the Board is entitled to a preliminary injunction upon demonstrating "a reasonable apprehension that the efficacy of the Board's final order may be nullified, or the administrative procedures will be rendered meaningless"293 unless temporary relief is granted. Similarly, the Federal Trade Commission Act provides that the FTC may obtain a preliminary injunction against certain types of

289 Id. at 659.

$290 \mathrm{Id}$.

291 See, e.g., SEC v. Jones, 85 F.2d 17 (2d Cir.), cert. denied, 299 U.S. 581 (1936) (lack of adequate remedy at law need not be alleged); Henderson v. Burd, 133 F.2d 515 (2d Cir. 1943) (irreparable injury need not be shown). For criticism of relaxing the traditional requirements of equity in certain circumstances, see Developments in the Law-Injunctions, 78 HARV. L. Rev. 994, 1059 (1965).

$282 \S 10(\mathrm{j}), 29$ U.S.C. $\$ 160(\mathrm{j})(1970)$.

293 Angle v. Sacks, 382 F.2d 655, 660 (10th Cir. 1967); see NLRB v. Aerovox Corp., 389 F.2d 475, 476-77 (4th Cir. 1967); Elliot v. Dubois Chemicals, Inc., 201 F. Supp. 1, 2-3 (N.D. Tex. 1962). 
false advertising on a "proper showing" that it has "reason to believe" the advertising violates the law. ${ }^{294}$ In FTC v. Rhodes Pharmacal Co., 295 the court held that an injunction should issue under the statute, without regard to the existence of debatable issues of fact, if the Commission demonstrated "a justifiable basis for believing, derived from reasonable inquiry or other credible information, that such a state of facts probably existed as reasonably would lead the Commission to believe that the defendants were engaged in the dissemination of false advertisements of a drug in violation of the Act." 296

Two considerations suggest the wisdom of a legislative decision to relax the burden of proof that an administrative agency must meet to obtain a preliminary injunction. First, modifications in the agency's burden of proof that relieve it from certain evidentiary obligations can increase its opportunity to obtain expeditious relief from the courts. Second, the less demanding the burden of proof that an agency must meet, particularly on the traditional equity standard regarding its likelihood of prevailing on the merits, the more remote the possibility that its decision to seek a preliminary injunction will appear to commit itor will in fact commit it-to a position "at odds with its subsequent supposed impartiality when called upon to decide the case on its merits."297

When Congress permits an administrative agency to obtain a preliminary injunction by meeting a relaxed burden of proof, it reduces proportionately the scope of an equity court's traditional authority. Congress has not yet chosen to restrict that authority drastically; but by sufficiently modifying the traditional requirements of equity, Congress could enable an administrative agency to obtain a preliminary injunction almost as readily as it could take summary action, particularly when account is taken of the courts' tendency to defer to the judgment of agencies seeking statutory injunctions. ${ }^{298}$ This approach may at first seem appealing. In comparison to summary action it places only mar-

204 § 13(a), 15 U.S.C. § 53(a) (1970).

295191 F.2d 744 (7th Cir. 1971).

296 Id. at 747-48. But see FTC v. National Health Aids, Inc., 108 F. Supp. 340, 346 (D. Md. 1952); Note, supra note 285, at 486-87 n.54.

297 Elman, supra note 157 , at 811 (footnote omitted).

298 See United States v. First Nat'l City Bank, 379 U.S. 378, 383 (1965); Hecht Co. v. Bowles, 321 U.S. 321, 331 (1944). Compare Brown v. Pacific Tel. \& Tel. Co., 218 F.2d 542, 544 (9th Cir. 1954) (Pope, J., concurring): ("[T]he area for the exercise of the traditional discretion not to grant an injunction is much more limited" in the presence of a statute.) with FTC v. Sterling Drug, Inc., 317 F.2d 669, 677 (2d Cir. 1963) ("Not even the Commission contends that ... the judge is merely a rubber stamp, stripped of the power to exercise independent judgment on the issue of the Commission's 'reason to believe." "). 
ginally greater restraints on an agency's capacity to act effectively, yet it grants the individual an opportunity to contest the agency's proposed action before a judge. But its implications are disquieting. Narrowing the scope of the court's authority so severely would compromise the fundamental values that justify requiring resort to the courts for the judicial remedy of a preliminary injunction in the first place. By purchasing the appearance of judicial participation without providing its substance, this approach would diminish the stature of the federal courts and trifle with their prestige.

These judgments do not counsel Congress against modifying the traditional equity standards for issuance of preliminary injunctions when greater flexibility than they permit is appropriate. They do suggest, however, that if Congress chooses to authorize an administrative agency to seek a preliminary injunction rather than grant it summary authority, it should preserve for the courts a role that draws upon, rather than compromises, their special strengths and historic authority.

\section{The Ghallenge of Summary Action}

Fair administrative procedure most often results when Congress and the administrative agencies share with the courts the responsibility for creating it. The Administrative Procedure Act has been successful in achieving greater fairness in the formal processes of adjudication and rule making because Congress, in drafting its central provisions, struck a workable balance between prescribing fundamental principles of fair procedure and permitting administrative agencies freedom to adapt these principles creatively to the disparate patterns of their regulatory responsibilities.

A challenge of the character that the draftsmen of the Administrative Procedure Act faced in 1946 now confronts those concerned with the fairness of the informal, discretionary processes of administrative agencies. Although the importance of informal agency action has been recognized for a generation, only recently have students of the administrative process begun to suggest systematic approaches to understanding its nature.

Of the many informal processes that administrative agencies engage in, summary action is particularly appropriate for thoughtful study. As an exception to the general constitutional norm that government may not act against an individual before it has granted him a hearing, it has the competence to permit effective governmental action in emergency situations as well as the capacity wrongfully to inflict serious injury. Yet its exercise is almost wholly free of administrative regulations or formalized agency practices. The Supreme Court has recently 
begun to reexamine and refine the constitutional principles governing the area. Summary action, in short, is ripe for contemporary consideration. One can hope, as Professor Frankfurter wrote of his generation's quest to understand the administrative process, that "efforts at systematization may themselves be creative forces." 299

299 F. Frankfurter \& J. Davison, Cases and Other Materiats on Administrative Law viii (1932). 